\title{
Italian-Style Opera Houses: A Historical Review
}

\author{
Dario D'Orazio ${ }^{+}(\mathbb{D}$ \\ Department of Industrial Engineering, University of Bologna, 40136 Bologna, Italy; dario.dorazio@unibo.it; \\ Tel.: +39-051-2090549 \\ + Current address: Viale Risorgimento 2, 40136 Bologna, Italy.
}

Received: 18 May 2020; Accepted: 24 June 2020; Published: 3 July 2020

\begin{abstract}
Attending an opera involves a multi-sensory evaluation (acoustical, visual, and more), cultural background and other emotional parameters. The present work aims to investigate the historical development of Italian-style opera houses, from the 16th century until today. Called "Italian" due to their origin, they developed thanks to the mutual influence of the genre and the building characteristics. Furthermore, the acoustics of historical opera houses is now considered as intangible cultural heritage, so it should be known and preserved. The paper addressed the state-of-the-art literature-most of which was proposed in Italian — which can be driven easily by the sharing of historical and contemporary knowledge.
\end{abstract}

Keywords: acoustics; opera house; intangible cultural heritage

\section{The Social-Historical Context}

\subsection{The Birth of the Genre: The Early Age of Opera House}

The word Opera in Latin is the plural of opus, which means "act, performance". Thus, opera means the simultaneous act of a performer-including their voice and gestures-and music. Florence and its 16th-Century cultural influences are commonly accepted as the birthplace of Opera. This kind of performance acquired a semi-public dimension, such as the Teatro Mediceo in Florence (1586). After Florence, some North-Italian courts hosted opera composers and independent architectures were opened to the ruler and the court [1]. In the Venetian area, the Teatro Olimpico, Vicenza (1585) [2] were designed by A. Palladio (1508-1580); in the courts of Milan, the Teatro all'antica, Sabbioneta (1590) by V. Scamozzi (1548-1616) [3]; in Parma, the Teatro Farnese (1618, damaged during WWII and rebuilt) $[4,5]$ by G. B. Aleotti (1546-1636); by the same architect, in Ferrara, the Teatro degli Intrepidi (1604, burned in 1679) [6]. In these early spaces designed for melodrama, one of the most significant aspects is the structural and typological background, deriving from the form of the Roman architecture, including the Roman theatre [7]. This latter was called 'Ancient theatre' until the 18th Century $[8,9]$, in contrast with the 'new theatre' for opera.

The turning point in the opera-house history was 6 March 1637, when all social classes attended the inauguration of the San Cassiano theatre in Venice. The paying audience led to a redefinition of the theatre shape: it made it possible to plan the theatrical seasons and the related investments, thus building permanent structures. During some years, several similar theatres were built in Venice, often named by the nearest church: Ss. Giovanni e Paolo, 1638; Novissimo 1640; San Moise 1640; San Giovanni Grisostomo (now Malibran) 1678 [10]. These latter cited opera houses allowed the development of opera as we know it today. Indeed, these halls hosted the second generation of opera composers, F. Cavalli (1602-1676), A. Cesti (1623-1669), who exported the opera outside of Italy, respectively in France and in Austria; in the early 18th Century the operas of A. Vivaldi (1678-1741) and then the evolution of the so-called Neapolitan School-among others, D. Scarlatti (1685-1757), G.B. Pergolesi (1710-1736), G. Paisiello (1740-1816), D. Cimarosa (1749-1801). Before 
the demolition, some of these theatres were used until the 19-Century hosting the representation of G. Rossini (1792-1868) and G. Donizetti (1797-1848). In other words, they were used from the birth of melodramma in the early 17th Century to its standardisation in the 19th Century. On one hand, this means that the geometrical form was useful to visual and acoustic needs of the audience [11]. The Basilica form of the early court-theatres did not have satisfactory acoustic requirements for this novel kind of performance. On the other hand, these typologies of theatres could justify by hosting enough paying spectators the affordability of new developments/constructions for the opera manager. The role of the 17th-Century Venetian managers in reviewing the acoustics of opera should be acknowledged [12]: thanks to commercial documents is possible to know, today, all the details about orchestras, audience, representations [13,14].

The theatre of Ss Giovanni e Paolo (1638) was probably the earliest one hosting audience in the boxes [10,15] (see Figure 1). As a matter of fact, the early court theatres did not need a large attendance because they hosted the court only. Instead, the public Venetian theatres needed to increment the seating capacity and improve the visual conditions of the attending public. At the same time, the upper classes began to claim independent and private spaces, leading to the building of wooden partitions on the different tiers, creating the so-called "boxes". This spatial division reflected the social subdivision into classes. As cited by Venetian chronicler C. Ivanovich (1620-1689) [16]:

“Giravano d'intorno cinque file di loggie l'una sovraposta all'altra con parapetti avanti a balaustri di marmo ....Le due piú alte, e piú lontane file [di logge] erano ripiene di cittadinanza, nella terza sedevano i signori Scolari, e i nobili stranieri, il secondo come luogo piú degno era dei Sig. Rettori e de' Nobili veneti, e nel primo se ne stavano le gentildonne, e i principali gentilhuomini della cittá". (Five tiers of boxes went round, one on top of the other, with marble balustrades. The upmost and furthest two tiers [of boxes] were stuffed with ordinary citizens, in the third one sat Scholars and foreign nobility, the second was reserved to Rectors and noblemen of the Venetian region, and in the first sat the gentlewomen, and main gentlemen from the city).

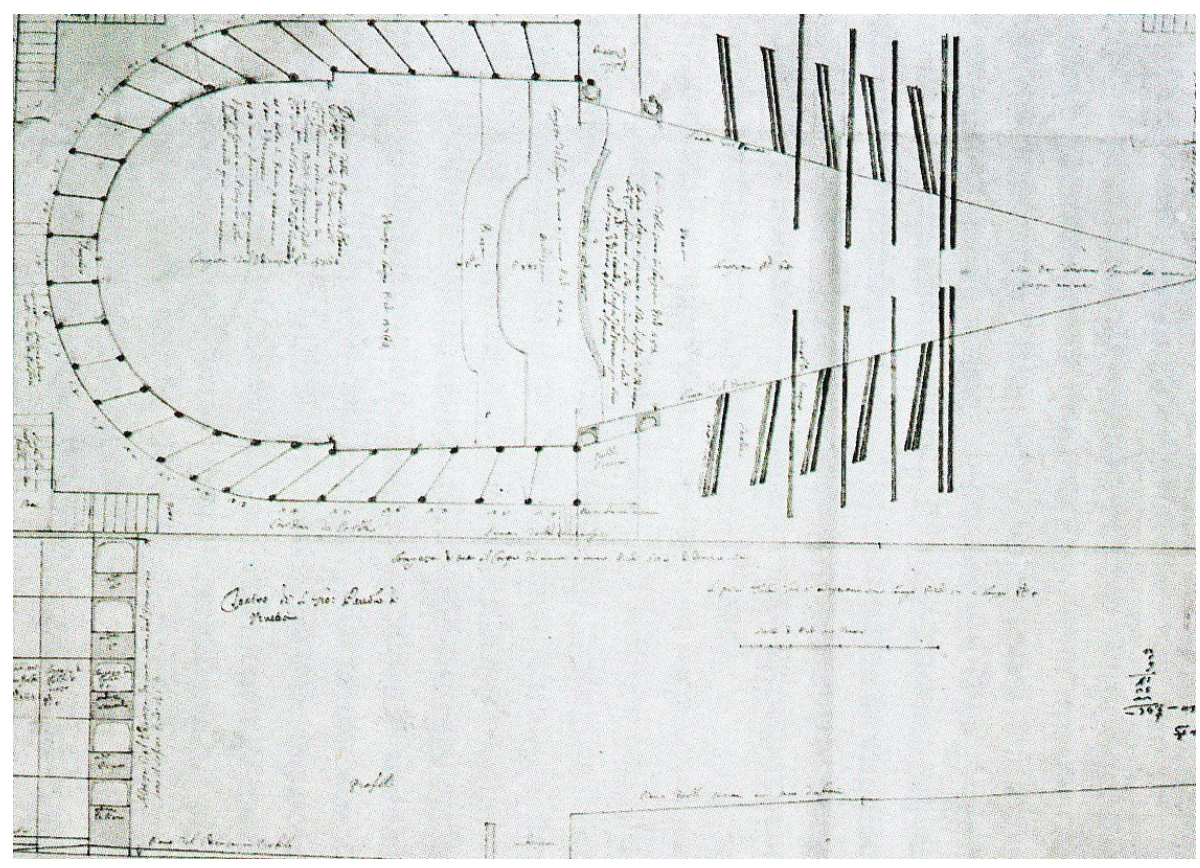

Figure 1. Plan of theatre of Ss Giovanni e Paolo, in Venice (1638). 


\subsection{The Influence of Italian Opera House Outside of Italy}

In 1637, the opera Andromeda by F. Mannelli (1595-1697) marked the birth of Libretto. This was a booklet which included the score of the opera, the parts of the soloist and a very detailed description of the scene and of the scenic actions. This allowed to reply the same opera in different places. By this way, the opera was exported outside of Italy. In 1645, the first opera in Paris, La Finta Pazza, was presented. Some Italian composers, such as the aforementioned Cavalli or Giovanni Battista Lulli (1632-1687)—also know as Jean-Baptiste Lully—influenced the early French opera composers, such J.-P. Rameau (1683-1764).

As well as the contents, i.e., the opera, Italy exported also the container, i.e., the opera house. As a paradigmatic example, the Galli-Bibiena family of architects moved from Italy to European Courts, working as scenic artists and opera-house architects [17]. They designed around the Europe: Grosse Hoftheater, Wien (1708); Great Theatre at Nancy (1709); Teatro Filarmonico, Verona (1719, burned in 1749); Teatro Alibert, Rome (1720); Mannheim Opernhaus (1719, burned in 1795); Royal Theatre, Mantua (1731, burned in 1781); Markgräfliches Opernhaus, Bayreuth (1748) [18]; Dresden opera (1750, burned in 1849); Ópera do Tejo, Lisbon (1752, ruined in 1755); Teatro Rossini, Lugo (1760) [19,20]; Teatro Comunale, Bologna (1763) [21-23]; Teatro de Quattro Cavalieri, Pavia (now Fraschini, 1773) [24,25]; Scientific theatre, Mantua (1775, now Bibiena), and many others [26].

The development of the opera house building was closely related to the development of the opera and the society. In Italy, between the late 17th and the 19th Century, there was a debate on the form of the opera house [27]. The first essay dealing with the so-called "Italian theatre" was written by the architect F. Carini Motta (death 1699) [28]. The author recognised the different typologies: the 16th-Century Court theatre with steps, with boxes or galleries, with boxes joined or not joined with the proscenium. Regarding this latter one, he proposed two different models of the horseshoe plan typology. In order to increase the width of the proscenium and increase the visibility of the stage, some authors-as F. Algarotti (1712-1764) [29], F. Riccati (1718-1790) [30], A. Memmo (1729-1793) [31] — proposed the bell-shape plan, the one used by the already mentioned Galli-Bibbiena architects in all they works. An alternative proposal was the elliptic shape, proposed by theorists [32], but also used by C. Morelli (1732-1812) [33] —one of the most influential architect of the Papal State-for building the theatre of Imola (1780, now Stignani Theatre), or by A. Petrocchi for the theatre of Lugo (1758-1760, now Rossini Theatre). The instances of the Enlightenment [34] were followed by theorists Enea Arnaldi (1716-1794) [35] and Francesco Milizia (1725-1798) [36]. Influenced by some of the French designs [37,38], they published on the topic of the "ideal theatre". Milizia exalted the semi-circular ancient theatre, where all the spectators were able to see and hear properly, while the modern theatre with boxes did not allow satisfying visuals to the whole public [39]. T. C. Beccega (17??-18??) tried to match the Graeco-Roman architecture to the construction of the Modern Italian Theatre [40]. He followed the Vitruvius's theory and, at the same time, he tried to develop a theatre standard, whose shape was a semi-circle with elongated extremities. Unfortunately, none of these ideal designs were built. A virtual simulation of V. Ferrarese's theatre, based on Milizia's ideal theatre, has been proposed and discussed in recent years [41].

Until the 20th Century, the theatres were built by wooden structures, with very few exceptions built with masonry-such as the aforementioned Teatro Comunale in Bologna (1763). As seen, theatres were periodically ruined by fires. This might be the reason that triggered the evolutionary process of the theatrical form [42]. In the early 19th Century, the form of the opera house should be considered already evolved, with the works of Piermarini-who designed La Scala theatre in Milan —and Niccolini [43] — who rebuilt the San Carlo theatre in Naples. This form was defined around some fixed points: the materials, the horse-shoe shape, the dimension (four tiers of boxes and a gallery with very few exceptions, a cavea volume of about 6000-10,000 $\mathrm{m}^{2}$ ) [44].

Figure 2 shows the evolution of theatres in Italy: after the initial period of court theatres (1585-1637), the evolution of the form as it has been discussed, and the 19th century provided the dissemination of opera house. In order to host the main representations, in each city a mid- or 
large-sized theatre was built. According to Prodi et al. [44], a 'mid-sized' group means a volume of the main hall between $3000 \mathrm{~m}^{3}$ and $9000 \mathrm{~m}^{3}$, corresponding to a current occupancy of 800-1000 people. A 'large-sized' group means a volume larger than $9000 \mathrm{~m}^{3}$, corresponding to more than 1300 seats.

As an example, in Venice the small 17th century theatres were replaced by the La Fenice theatre, which was built for the first time in 1792 [31] and rebuilt in 1837 [45]. Technical essays of this period seems to confirm a well-consolidated technical knowledge [46,47]. The authors revealed the knowledge of the European discussion on the opera-house acoustics. To confirm this, the design of the last large 19th century opera house, the Vittorio Emanuele Theatre in Palermo (now Teatro Massimo, 1897), shows the influences of the contemporary great opera houses of the time [48].

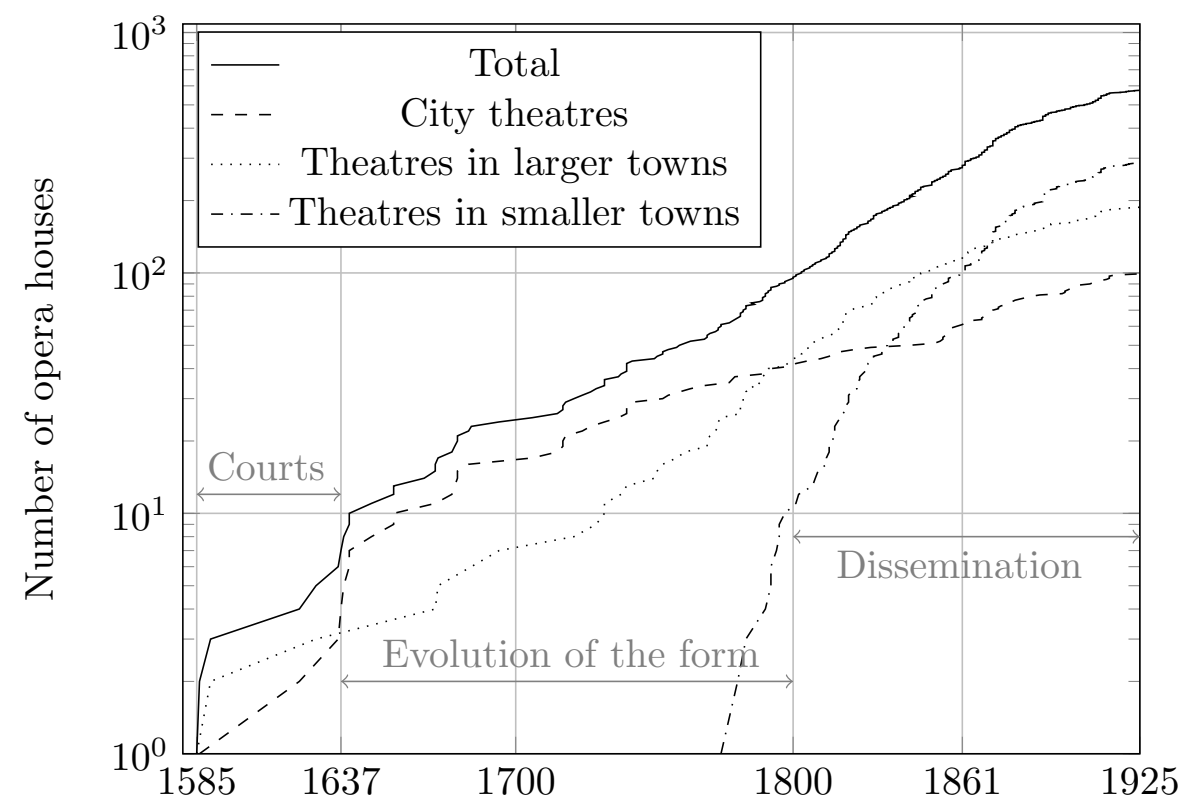

Figure 2. Progression of opera houses in Italy from 1585 to 1925.

In the United Kingdom, the early opera developed based on Elizabethan theatre, through composers such as H. Purcell (1659-1695) and G. F. Händel (1685-1759). Nevertheless, the English opera did not have a 19th century development comparable the other European tradition. Until the middle of 19th century the Covent Garden [49] theatre hosted performances in baroque style. There was a coexistence of English, French, and Italian tradition. Concerning the design of theatres, it should be remarked Saunders's work [50], who surveyed the dimensions of the ancient and the modern theatres, founding the most advantageous form for the voice and sight. His works was rediscussed in a contemporary way in several papers on Pre-Sabinian design criteria [51-53]. After the birth of architectural acoustics as a science, the engineer H. Bagenal (1888-1979) and the physicist A. Wood (1879-1950) collected the first pioneristic acoustic survey on theatres and opera houses [54].

In the aforementioned French tradition, after the first one lead by Rameau, the new National-opera, called Comédie Francaise and the Italian-style opera, the Comédie-Italienne, coexisted. The Enlightenment debate and, then the French Grand Opera, moved away from Italian tradition, both in opera-style and in buildings. About the first point, the late 18th-Century theorists proposed designs where the architecture reflected the social ideals of equity, in contrast with the social in-equities of Italian opera houses. Although there were many designs, the only built theatre was the Musical Theatre of Besançon by C-J. Ledoux (1736-1806) [37]. About the second point, the Grand-Opéra-which was usually dated back to La Muette au Portici (1828) written by D. F. Auber (1782-1871)—needs larger opera houses. The prototype of this new kind of opera house was the new opera house in Paris (1875), designed by C. Garnier (1825-1898). The architect declared intentionally-and probably provocatively declared — to do not follow any acoustic instance in his work [55]: 
“je n'ai adopté aucun principe [...] je ne me suis basé sur aucune théorie [...] c'est du hasard seul que j'attends ou l'insuccés ou la réussite" (I have not adopted any principle [...] I did not base myself on any theory [... ], I wait for either failure or success by mere chance).

He designed tiers of gallieries instead of tiers of boxes, aiming to democratise the opera attendance. The fact remains that, after the Paris Opéra (now Opéra Garnier) - and after the almost contemporary Bayreuther Festspielhaus (1876) [56,57], the gallieries gradually replaced the boxes in opera houses, allowing a better visual and a larger attendance of public.

In the Austrian-German culture, the 18th-Century opera was characterised by C W. Gluck (1714-1787) and then W.A. Mozart (1756-1791), both in a dialectical relationship between a new opera in German and the Italian opera, especially the Neapolitan school. For instance, after a century and a half, during the years 1783-1786, the Performance Calendar for the National Court Theatres in Vienna provided only operas wrote in Italian [58]. The 'national' German opera was developed in the 19th Century, thanks to the work of C. M. von Weber (1786-1826) and, then, R. Wagner (1813-1883). This new German opera needed the building of new opera houses, such as the Dresden oper, by G. Semper (1803-1879) and the already mentioned Bayreuth Festspielhaus. It should be noted that some features, such as the stage inclination and the orchestra pit position-lower than the audience in the stalls - were previously proposed by theorists [40] and by architects—such as in the aforementioned Ledoux's Besançon theatre (1784, burned in 1958).

In the late 19th century the opera was exported to the Americas. The most relevant opera houses were the Academy of Music (1854, demolished in 1926) or the Metropolitan Opera (also known as MET-1883, rebuilt in 1966) in New York City, and the Teatro Colon (1908) in Buenos Aires [59]. These opera houses were built as a synthesis of what was done during the previous two centuries. For instance, in the old MET, there were three tiers of private boxes, where New York's powerful new industrial families - which also provided for building this new theatre-could display their wealth and establish their social prominence (see Figure 3). The interest of American people for the opera led some composers, such as G. Puccini (1858-1924), to write original operas inspired by the American tradition, such as Madama Butterfly (1904), Fanciulla del West (1914). The first representations of the latter one and the following Gianni Schicchi (1918) took place at Metropolitan Theatre in New York City. At the beginning of the 20th Century, the USA needed new theatres, and in one of these new opera house took place the first acoustical correction for such kind of spaces. It was made by W. C. Sabine (1868-1919), recognised as the founder of the architectural acoustics, who proposed to place a canopy on the vault in order to modify the reflections from ceiling [60]. Despite this, the theatre was demolished, due to its poor acoustics.

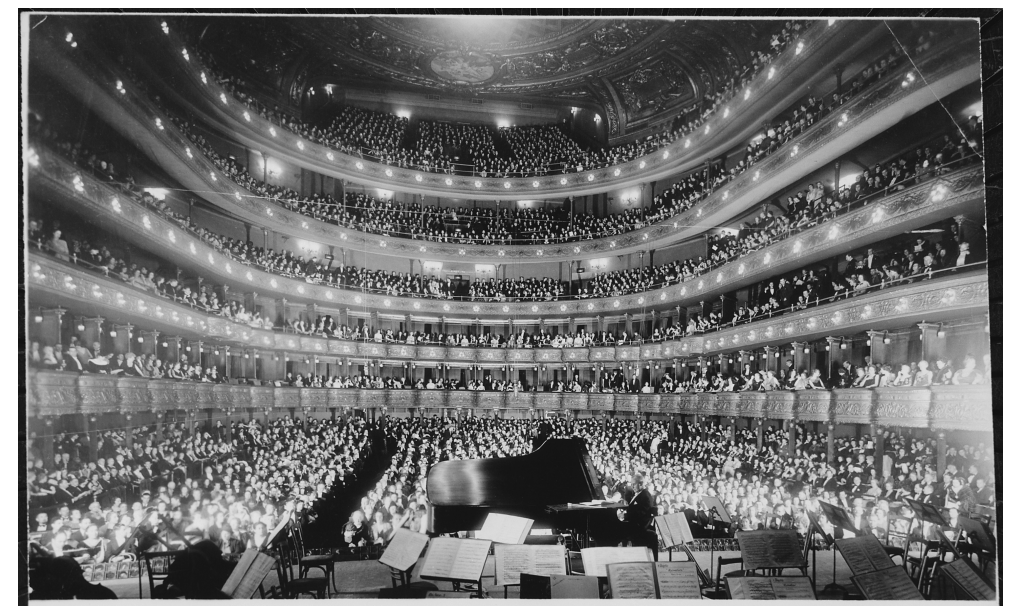

Figure 3. A concert by pianist Josef Hofmann in the old Metropolitan Opera House in 1936. National Archives at College Park/Public domain. 


\subsection{The 20th Century}

The 19th century was also the age of the new houses of parliament, due to the new political asset of European Monarchies. Indeed the word "Parliament" appeared at the time of the French constitutional monarchy of 1830-1848: the French parliament house (Palais Bourbon) was renovated in 1828, the English one (Palace of Westminster) was rebuilt in 1847-52, the Italian one (Palazzo Montecitorio) was built in 1871 and renovated in 1903 by E. Basile (1857-1932)—who was the architect of the already mentioned Teatro Massimo in Palermo. The intelligibility of a single speaker in a hall occupied by about one thousand people became a new instance for the acousticians of this period [47].

The 20th Century marked also the birth of Cinema, and-thanks to the 'new' electronic features - the gradual replacement of a real orchestra by a reproduced music. Acousticians seemed to curb their interesting in opera house. Moreover, the sound of singers and orchestra started to be enhanced by electro-acoustics [61].

Opera survived, but was in need of some changes. On one hand, the performances required more spaces-this was one of the reason of the rebuilt of 'old' MET into the new hall at Lincoln Center in the 1960s [62] (see the timeline in Figure 4). On the other hand, the opera houses became 'iconic' buildings, to the partial disadvantage of their acoustic function. This was the largely debated case of Sydney Opera house, whose long building process (1957-1973) forced the acoustic to deal with new instances in architectural acoustics [63].

During 1950s and early 1960s a comparative analysis between subjective and objective parameter were used by L. L. Beranek [64] as a preliminary study in order to design the acoustics of the new Philharmonic Hall (rebuilt during the 1970s as Avery Fisher Hall, from 2015 renamed as David Geffen Hall), in the complex of Lincoln Center. The acoustic design was optimised for the acoustic intimacy, which seemed to be the most important subjective attribute in the previous survey. As a matter of fact, the acoustics of the new Philharmonic hall was inadequate and in the hall was renovated. The failure was due to several reasons, most of which are not imputable to Beranek's design.

In the early 1990s, L. Beranek-who left the acoustic design activity after the Philarmonic Hall failure [65] — was asked by Hidaka to collaborate for the acoustic design of the new Tokyo Opera House [66]. Several international opera houses were surveyed again [67], and new acoustic criteria were taken into account [68].

In Italy, in 1992 the fire destroyed Petruzzelli theatre in Bari. The same fate, in 1996, for La Fenice theatre in Venice. After these unfortunate events, Italian scholars were committed to recognise the acoustics of Italian Historical Opera House as intangible cultural heritage [69-72]. 


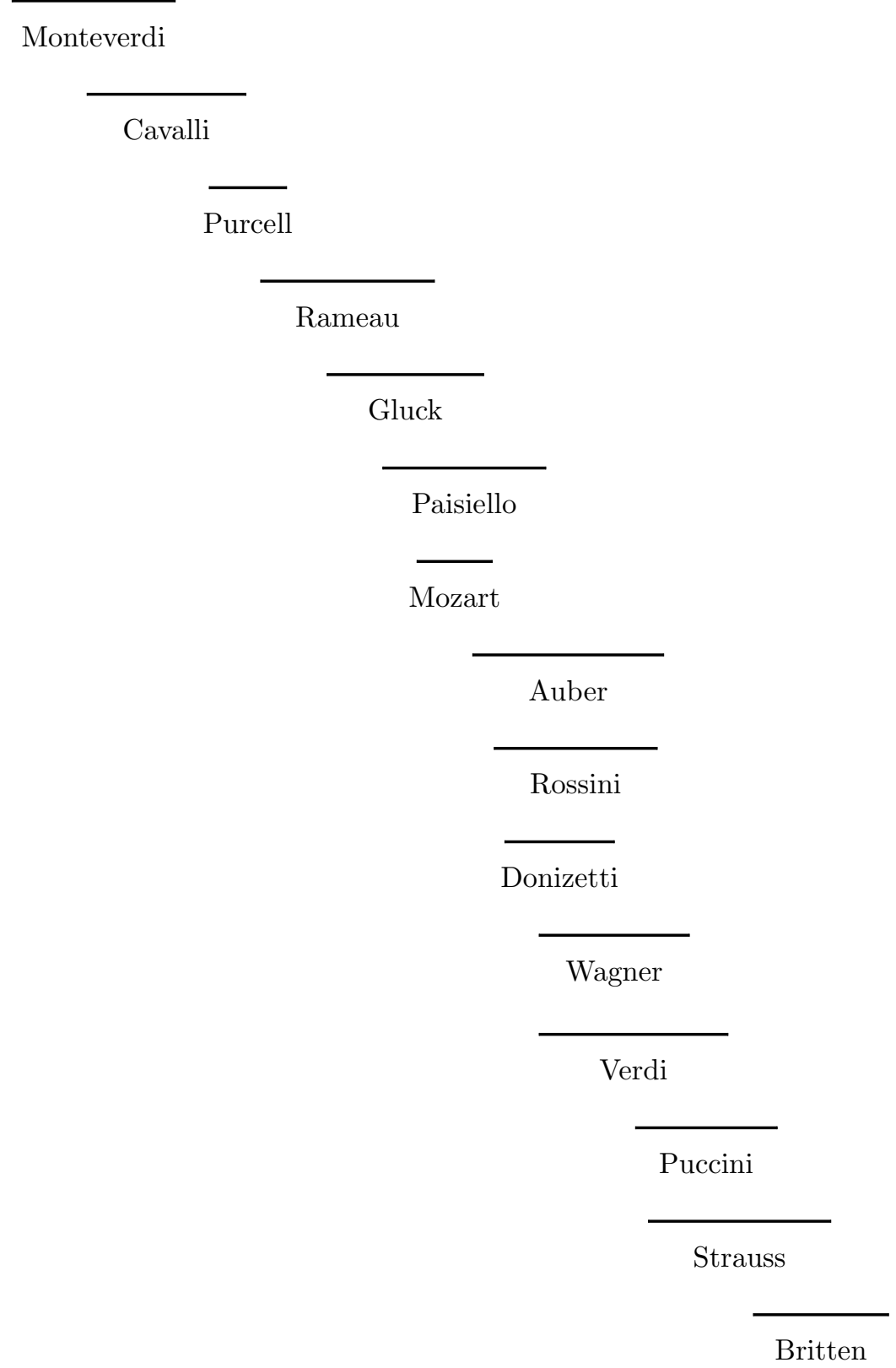

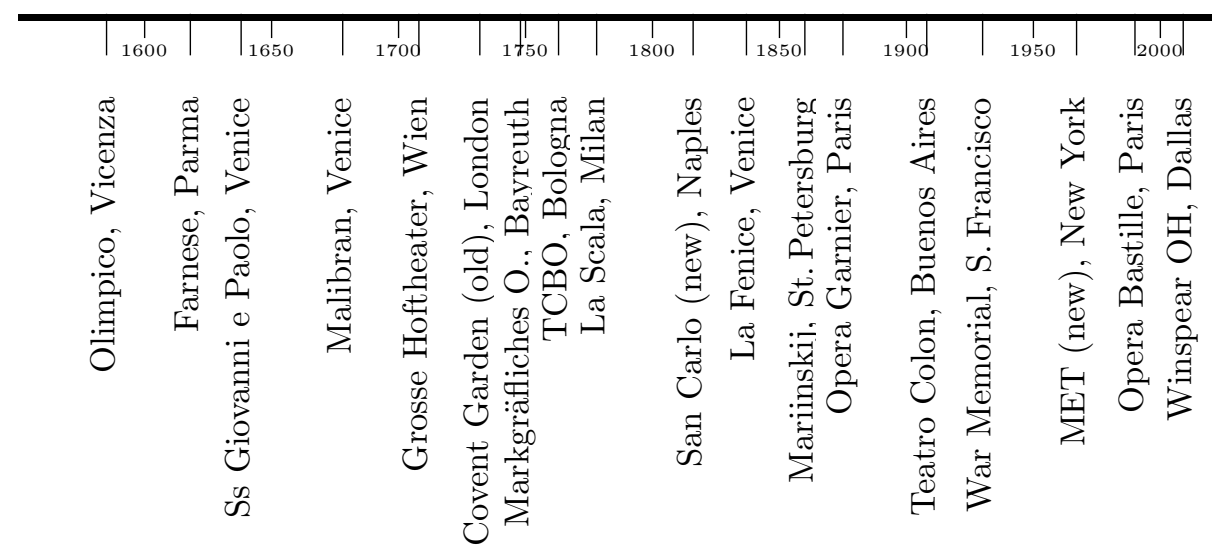

Figure 4. Timeline of some of mentioned opera houses of and life span of some of mentioned composers. 


\section{Italian-Style Opera Houses: A Chronotaxis}

\subsection{Dissemination}

Depending on the construction year, Italian opera houses can be divided into four categories:

1585-1637 Court theatres of Northern Italy, unopened to the public. They host the early operas, played by instruments and voices different from the today ones. Despite this, these early-age theatres get almost all the peculiarities of the future opera house. For this reason, they were exhaustively measured and simulated by scholars [5].

1637-1800 Public theatres, opened earlier in Venice and later in the main cities. This period marked the evolution of the form. The scholars discussed and wrote on the best shape, the right dimension and the proper materials [27]. Opera houses were built and quickly demolished, often due to fires. This may be viewed as a genetic selection: only the best-sounding theatres were rebuilt using the same materials and techniques, otherwise different ways to build were tested [42]. The interest of people in opera increased during this period, leading to the need for larger opera houses. The goal of theatre-designers was to assure the best stage-visibility for a largest number of people. This means having the widest proscenium arch with respect to the hall dimensions. The horse-shoe shape emerged as the best compromise between these two reasons. Most of the opera houses in the largest cities were build in this period: la Pergola in Florence (1656) [73], Argentina in Roma (1732), San Carlo in Naples (1737, burned in 1816 and rebuilt in 1817) [74,75], Regio in Torino (1740, burned in 1936), Comunale in Bologna (1763), [21,23,73,76,77], La Scala in Milan (1778) [73,78,79], La Fenice in Venice (1792, burned in 1836 and rebuilt in 1837, burned again in 1996) [80].

1800-1925 Until 1861, Italy was still divided into pre-unitarian states. In this period the theatrical form was well defined, and it was replied in order to have a opera house in each town. As shown in Figure 5, this dissemination process varied depending on pre-unitarian state, earlier in the Kingdom of Lombardy-Venetia, then in the Grand Duchy of Tuscany and in the Papal State, later in the Kingdom of Two-Sicilies and in the Kingdom of Sardinia. There were social and cultural reasons to this temporal misalignment, but after the Italian unification the differences were diminished. In Italy, opera played a role of unification between people who spoke slightly different languages and had somewhat different cultures. For instance, during the Risorgimento process, the sentence "W V.E.R.D.I." was used also as acronym, meaning "W Vittorio Emanuele, King of Italy". Furthermore, some G. Verdi's operas, such as Nabucco (1842) or I Lombardi alla Prima Crociata (1843), hidden the revolutionary instances of the Lombard people which was under the Austrian government until 1861. It should be noted the case of peripheral regions of the Papal State-corresponding today to Umbria, Marche and Romagna regions-in which each city, large or little town was provided by its own opera house. A huge number of these small-sized theatres still exist. Some of them were surveyed by local studies, such as in the case of Campania [81], Romagna [20], Marche [82], Puglia [83], and Veneto [84]. Due to the well-defined form, architects repeated the same project with few variations. Indeed, theatres built in the same geographical area and in the same years often shared the same workers and same building techniques. Due to the large number of small/mid-sized opera house, a "regional" typology can be identified. 

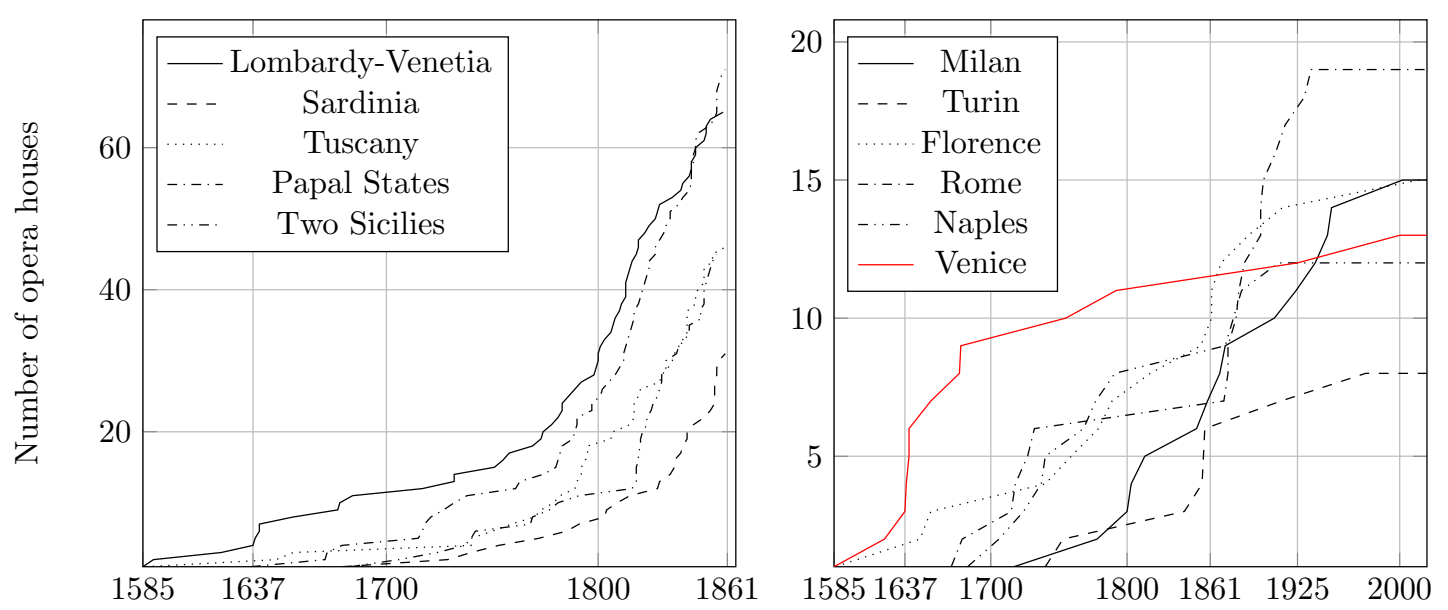

Figure 5. Dissemination of opera houses in the pre-unitarian states (left figure) and in the corresponding most important cities (right figure).

Moreover, several large-sized theatre were built at the end of the 19th century in Rome (from 1871) and in the South of Italy. Among others, they should be mentioned the Costanzi theatre in the new Rome (1880, renowned in 1928) [85], the Bellini theatre in Catania (1890) [86], the Massimo theatre in Palermo (1897) which is still today the largest Italian opera house-and the Petruzzelli theatre in Bari (1902, burned in 1992). The design of these latter opera houses was influenced by the instances of most recent European opera houses. There were both boxes and galleries-two tiers of galleries instead of the Loggione. The scenic arch was much wider than previously, as in the case of Massimo theatre in Figure 6. Indeed, the Verdian orchestra was larger than the previous tradition $[87,88]$ an the soloists needed to increase their sound strength. In order to reach the proper balance, architects extended the stage, through the so-called proscenium, below the arch. This latter was tilted for two reasons: to reflect the singer's voice on the audience and avoid the flutter echo effects for the orchestra. It should be noted that in some cases, such as the Costanzi and Massimo theatres, the orchestra floor can be also lowered, as "the most recent German theatres" [48].
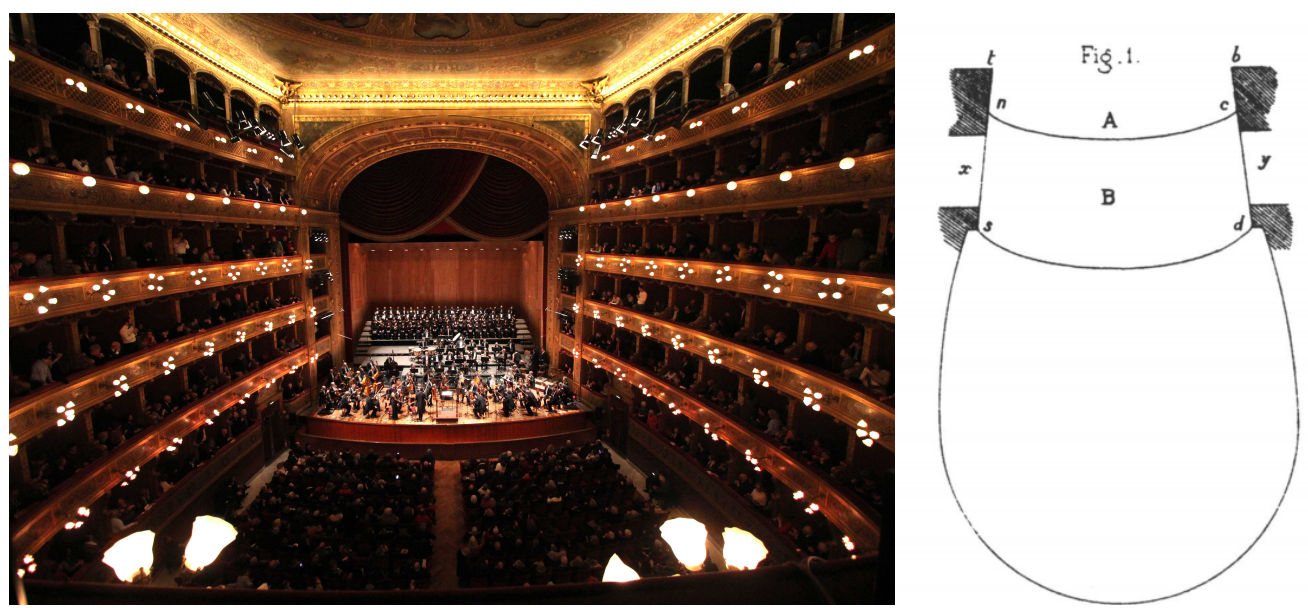

Figure 6. On the left: Proscenium arch of Massimo Theatre in Palermo; Reproduced with permission from Teatro Massimo, Copyright Franco Lannino, 2020. On the right: plan of Massimo theatre in Palermo $A$ : proscenium, $B$ : orchestra; $b t s d$ : proscenium arch; $x, y$ : stage boxes. 
1925-today Opera houses were replaced by cinemas. Often, opera houses were converted to cinemas and then progressively abandoned. Sometimes, such in the case of the Romagna in the 1970-1980s [89], the refurbishing of a group of these abandoned opera houses was managed by local government. Otherwise, the restoration has been based on a public debate [90]. Several opera houses, damaged by bombs during the WWII, had to be rebuilt. Most of the remaining historical theatres needed refurbishments due to age, or adjustments to the needs of new kind of performances. These two points involved the acoustician debate, and will be treated in the next sections.

\subsection{Refurbishments}

Due to reasons which will be discussed in a next section, during the 20th Century almost all opera houses were modified in order to create the orchestra pit. In some cases, the orchestra pit replaced the proscenium area, so the stage was reduced. This choice influenced the acoustics of the opera house, because the soloist is moved back and the strength of his/her voice decreases [91]. Such a kind of intervention was usually done without an acoustic consultancy.

To the author's knowledge, the early acoustic consultancy in this field was done by G. Sacerdote and C. Bordone, concerning the renovation of De La Sena theatre of Feltre [15]. Afterwards, case studies were documented by Cocchi et al. [92,93]; Tronchin and Farolfi-theatre of Gradisca d'Isonzo [94]; Pisani [95]; Facondini [96]—Rossini theatre of Pesaro; Fausti et al. [97]—Valli theatre of Reggio Emilia. It was with the burning of the La Fenice theatre [98] that the interest in this field increased. The acoustics of historical opera house was recognized as intangible culturale heritage [71,72].

When some materials are changed or removed, the acoustic quality can dramatically change. This was the case of wooden acoustic cavities in the stalls of Alighieri theatre in Ravenna, removed during refurbishment works [99]. A more recent works in the same theatre was focused on the replacement of the wooden stage [91]. Both of these interventions have influenced the acoustic quality of the theatre, reducing the reverberation.

\subsection{New Buildings}

During the 19th Century, as shown in Figure 2, opera houses were disseminated. This means that operas were represented in larger cities as well as in little towns. Nowadays, it is still the same. Table 1 shows the statistics of season 2018-2019 for the lyrical performances collected for country/city for various national contexts. In some countries-e.g., USA, Russia and France-the performances are concentrated in one or two main cities. In other countries, e.g., Germany or Italy, the attendance is more distributed [100]. As a consequence, opera houses were still designed and built, or re-built, in the last decades in Italy.

Table 1. Opera performances vs. Cities. in the season 2018-2019. Data from operabase.com.

\begin{tabular}{|c|c|c|c|c|c|c|c|c|c|c|}
\hline & USA & & Russia & & Germany & & France & & Italy & \\
\hline 1 & New York & 277 & Moscow & 616 & Berlin & 625 & Paris & 429 & Milan & 170 \\
\hline 2 & San Francisco & 86 & St Petersburg & 539 & Hamburg & 419 & Lyon & 87 & Rome & 154 \\
\hline 3 & Philadelphia & 70 & Ekaterinburg & 94 & München & 396 & Marseille & 60 & Venice & 153 \\
\hline 4 & Chicago & 69 & Novosibirsk & 71 & Dresden & 357 & Strasbourg & 55 & Trieste & 137 \\
\hline 5 & Houston & 63 & Samara & 69 & Erfurt & 194 & Toulouse & 46 & Florence & 132 \\
\hline$\cdots$ & $\ldots$ & & $\ldots$ & & & & $\ldots$ & & & \\
\hline 10 & Seattle & 45 & Rostov-on-Don & 41 & Hannover & 161 & Nice & 31 & Bologna & 90 \\
\hline
\end{tabular}

Some opera houses were burned during the 20th Century [101], such as the aforementioned cases of Regio theatre in Turin (1936) [102], Petruzzelli in Bari (1992), La Fenice in Venice (1996). The Regio theatre was rebuilt in 1973, with the new design of C. Mollino and acoustic consultancy of G. Sacerdote [103]. La Fenice theatre and Petruzzelli theatres were rebuilt keeping the historical design [98]. They were reopened, respectively in 2004 [104] and 2009 [105]. 
Other opera houses were damaged during WWII: this was the case for the Carlo Felice theatre in Genua, damaged in 1943 and rebuilt with a new design of architect A. Rossi in 1991; the Teatro delle Muse in Ancona, damaged in 1943 and rebuilt in 2002, acoustic consultant: A. Cocchi [106]; the Galli theatre in Rimini was damaged in 1943 and reopened after a long debate, using the original L. Poletti's design, in 2018 [107]. The reconstruction of this latter one was followed by a large group of acoustic consultants—including the author of the present work [108].

Moreover, new opera houses were built: the Teatro Lirico opened in 1993, acoustic consultant: R. Pompoli [109]; the Arcimboldi theatre in Milan, inaugurated in 2001-architect V. Gregotti and acoustic consultant D. Commins [110]; and the new Teatro del Maggio Musicale Fiorentino in Florence (2011), whose acoustic consultant was J. Reinhold of MüllerBBM [111].

Finally, it should be mentioned the renovation of La Scala theatre in Milan during the years 2002-2004. The architect of the new fly tower was M. Botta, the acoustic consultant was H. Arau [78].

\section{A Taxonomy of Surveys, and Some Unresolved Instances}

Early measurements in Italian opera houses were done by Faggiani in 1930s [112,113]. After the WWII, it should be mentioned the pioneer work of G. Sacerdote, C. Bordone and the workgroup of National Institute of Standards and Technology "Galileo Ferraris" in Turin [15]. On the academic front, many research practices were based at the University of Bologna between 1970s and 1980s [114,115]. The amount of acoustic measures intensified in the 1990s, involving further research groups [86,116-118].

After a successful season of meetings in the 1990s, the community of scholars found standard procedures to qualify the acoustics of historical opera house $[119,120]$, collected in the so-called Ferrara charter. For instance, the Ferrara charter stated the use of dodecadrical sound source [121] instead of alternative sound sources [122] used in some early surveys [73]. Moreover, the charter stated how to place the source on the stage and in the pit [123], and how many receivers must be measured in the stalls and in the boxes [124]. By this way, the measurement campaigns done in the years between 2000 and 2010 returned comparable results, which were collected by Prodi et al. [44]. This work is also the source for measurement results and theathers' data, such as volume or occupation.

Tables 2-4 report a literature review of measurement campaigns, aiming to collect surveys on Italian-style opera houses (Tables 2 and 3), including the ones built outside of Italy (Table 4). The aforementioned classification of theatre by Prodi et al. [44] was used, based on volume of the main hall: small- $\left(V<3000 \mathrm{~m}^{3}\right)$, mid- $\left(3000<V<9000 \mathrm{~m}^{3}\right)$, and large-sized theatres $\left(V>9000 \mathrm{~m}^{3}\right)$. 
Table 2. Surveyed Italian-style opera houses built in Pre-unitarian Italian States (1585-1860). The "measurement" column specifies which kind of measurements were performed: $T$ means reverberation time, early decay time, and more; $C$ means, e.g., early-to-energy ratio, sound clarity, definition; $G$ means Sound Strength, $G_{E}, G_{L}$ using a calibrated sound source; $S$ means spaciousness criteria, such as Inter-Aural Crosscorrelation Coefficient (IACC), Cosine-Lateral fraction (LFC80), and more.

\begin{tabular}{|c|c|c|c|c|}
\hline Theatre(s) & Year & Size & Measurement & Repository \\
\hline Olimpico, Vicenza & 1585 & $\operatorname{mid}$ & TCS [4] TCGS [5] & CAD, IRs [125] \\
\hline All'antica, Sabbioneta & 1590 & small & TCS [4] TCGS [5] & CAD, IRs [125] \\
\hline Farnese, Parma & 1628 & large & TCS [4] TCGS [5] & CAD, IRs [125] \\
\hline La Pergola, Florence & 1656 & mid & TCS [73] & \\
\hline Malibran, Venice & 1678 & mid & TG [126] & \\
\hline del Pavone, Perugia & 1717 & mid & TCGS [44] & \\
\hline Filarmonico, Verona & 1732 & mid & TC $[44]$ & \\
\hline San Carlo, Napoli & 1737 & large & TCG $[44,74,75]$ & \\
\hline Verdi, Padova & 1751 & mid & TC [127] & \\
\hline Accademico, Castelfranco V. & 1758 & small & TC $[44,128]$ & \\
\hline Rossini, Lugo & 1761 & small & TCGS $[20,129]$ & \\
\hline Comunale, Bologna & 1763 & mid & $\begin{array}{l}\text { TCGS }[21,73] \text { TCGS }[22,44,77] \\
\text { TCGS }[23]\end{array}$ & CAD [130] \\
\hline Court, Caserta & 1769 & small & TC $[131]$ & \\
\hline Fraschini, Pavia & 1773 & mid & TCGS $[25,44]$ & \\
\hline Mercadante, Napoli & 1777 & mid & TC $[26,44]$ & \\
\hline La Scala, Milano & 1778 & large & $\begin{array}{l}\text { TCGS }[68] \text { TCS }[73] \mathrm{T}[78] \\
\text { TCGS }[44,79]\end{array}$ & \\
\hline Morlacchi, Perugia & 1781 & mid & TCGS [44] & \\
\hline Stignani, Imola & 1782 & small & TCGS $[20,129]$ & \\
\hline Zandonai, Rovereto & 1786 & mid & $\mathrm{T}[44]$ & \\
\hline Masini, Faenza & 1788 & small & TCGS $[20,129]$ & \\
\hline dell'Aquila, Fermo & 1790 & mid & TS [77] & \\
\hline Abbado, Ferrara & 1797 & $\operatorname{mid}$ & TCGS $[44,132]$ & \\
\hline Verdi, Trieste & 1801 & mid & TCS $[44,84,133]$ & \\
\hline Grande, Brescia & 1810 & mid & TCG $[44,134]$ & \\
\hline Sociale, Como & 1813 & mid & TC $[25,44]$ & \\
\hline Rossini, Pesaro & 1818 & mid & TC [96] & \\
\hline Sociale, Trento & 1819 & mid & $\mathrm{TC}$ [127] & \\
\hline Verdi, S. Severo & 1819 & mid & TCGS [83] & \\
\hline Garibaldi, Gallipoli & 1825 & small & TCGS [83] & \\
\hline Regio, Parma & 1829 & large & TGCS $[44,135]$ & \\
\hline Bonci, Cesena & 1846 & mid & $\begin{array}{l}\text { TC }[136] \text { TCG }[44,77] \\
\text { TCGS }[20,129]\end{array}$ & \\
\hline Petrarca, Arezzo & 1833 & mid & TC [137] & \\
\hline Milanollo, Savigliano & 1836 & small & TC [138] & \\
\hline Marrucino, Chieti & 1818 & small & TC [139] & \\
\hline La Fenice, Venezia & 1837 & mid & TCGS [80] & \\
\hline Garibaldi, Lucera & 1837 & small & TCGS [83] & \\
\hline Traetta, Bitonto & 1838 & small & TCGS [83] & \\
\hline Civico, Tortona & 1838 & small & TC [138] & \\
\hline Dragoni, Meldola & 1838 & small & TCGS $[20,129]$ & \\
\hline Fenaroli, Lanciano & 1841 & small & TC [139] & \\
\hline Pavarotti, Modena & 1841 & mid & [44] & \\
\hline di Bartolo, Buti & 1842 & small & $\mathrm{T}[44,140]$ & \\
\hline Goldoni, Bagnacavallo & 1845 & small & TCGS $[20,129]$ & \\
\hline Alighieri, Ravenna & 1852 & mid & TCGS $[20,91,129]$ & \\
\hline V. Emanuele, Messina & 1852 & mid & {$[94,141]$} & \\
\hline Verdi, Florence & 1854 & large & TCS [73] & \\
\hline Piccinini, Bari & 1854 & mid & TCGS $[44,83,142]$ & \\
\hline Baudi, Selve in Vigone & 1855 & small & TC [138] & \\
\hline Valli, Reggio Emilia & 1857 & mid & TCS $[44,97][143]$ & \\
\hline Alfieri, Asti & 1860 & mid & TCG $[44,144]$ & \\
\hline Chiari, Cervia & 1860 & small & TCGS $[20,129]$ & \\
\hline
\end{tabular}


Table 3. Surveyed Italian-style opera houses built in the unitarian Italy (1861-2020). Rebuildings are indicated by brackets. The "measurement" column specify which kind of measurements were performed: $T$ means reverberation time, early decay time, and more; $C$ means, e.g., early-to-energy ratio, sound clarity, definition; $G$ means Sound Strength, $G_{E}, G_{L}$ using a calibrated sound source; $S$ means spaciousness criteria, such as IACC, LFC80, and more.

\begin{tabular}{|c|c|c|c|c|}
\hline Theatre(s) & Year & Size & Measurement & Repository \\
\hline Guerrini, Benevento & 1862 & small & $\mathrm{TC}[44,127]$ & \\
\hline Menotti, Spoleto & 1864 & mid & TC [93] & \\
\hline Comunale, Cesenatico & 1865 & small & TCGS $[20,129]$ & \\
\hline Verdi, Pisa & 1867 & mid & $\mathrm{T}[44,140]$ & \\
\hline Mercadante, Cerignola & 1868 & mid & TCGS [83] & \\
\hline Verdi, Busseto & 1868 & small & $\mathrm{T}[114]$ & \\
\hline Del Monaco, Treviso & 1869 & mid & TCS $[44,84,94]$ & \\
\hline Verdi, Salerno & 1872 & mid & {$[44,75,145]$} & \\
\hline Curci, Barletta & 1872 & small & TCGS [83] & \\
\hline Paisiello, Lecce & 1872 & small & TCGS $[44,83,142]$ & \\
\hline R. Margherita, Caltanissetta & 1875 & small & $\mathrm{TC}$ [127] & \\
\hline Rossetti, Trieste & 1878 & mid & TC [127] & \\
\hline Comunale, Russi & 1887 & small & TCGS $[20,129]$ & \\
\hline Bellini, Catania & 1890 & large & TC $[86,127]$ & \\
\hline Van Vesterhout, Mola & 1896 & small & TCGS [83] & \\
\hline Massimo, Palermo & 1897 & large & TC [127] & \\
\hline Sociale, Rovigo & 1904 & mid & TCS $[44,84]$ & \\
\hline Comunale,Nardó & 1908 & small & TCGS [83] & \\
\hline Civico, Schio & 1909 & small & TC $[44,84]$ & \\
\hline Opera, Roma & (1928) & large & TCG $[44,85]$ & \\
\hline Comunale, Adria & 1935 & mid & TCS $[44,84]$ & \\
\hline Duse, Bologna & (1943) & mid & TCG [146] & CAD, IRs [147] \\
\hline TEA, Bologna & 1975 & large & TCGS [73] & \\
\hline Carlo Felice, Genova & $(1991)$ & large & TC [44] & \\
\hline Lirico, Cagliari & 1993 & large & TCG $[44,109]$ & \\
\hline Arcimboldi, Milano & 2001 & large & TCGS $[44,110]$ & \\
\hline La Fenice, Venezia & $(2003)$ & mid & TCS $[44,84,133]$ & \\
\hline Garibaldi, Bisceglie & (2003) & mid & TCGS [83] & \\
\hline Verdi, Brindisi & (2006) & large & TCGS [83] & \\
\hline Comunale, Gradisca d'Isonzo & (2009) & mid & TC $[44,148]$ & \\
\hline Petruzzelli, Bari & (2009) & large & $\mathrm{TC}[105]$ & \\
\hline Maggio Musicale Fiorentino & 2011 & large & TC [111] & \\
\hline Eschilo, Gela & $(2013)$ & small & TC [149] & \\
\hline Civico, Schio & $(2014)$ & small & TC [90] & \\
\hline Galli, Rimini & $(2018)$ & mid & TC $[107,108]$ & \\
\hline
\end{tabular}

However, there are still some unresolved instances. The first one concerns the setup of the fly tower during the measurements. It is well known that the presence or absence of draperies on the stage can influence significantly the sound behaviour at listeners' position [150,151]. Moreover, the sound source position in a coupled space can influence the sound energy decay $[129,146,152]$. The Ferrara-charter procedure states two positions of the sound source on the stage- the one in the fore-stage, the other one in the back stage-in order to 'average' the effects of coupling between the fly-tower and the cavea. Moreover, the Ferrara charter states a minimum amount of drapes in the fly tower-about $400 \mathrm{~m}^{2}$ in case of mid-sized opera house-in order to have a 'acoustic' scene comparable to the opera performance. Indeed, when the amount of drapes increases, the sound energy in the main hall decreases and the opposite one. Some scholars tried to measure the fly tower and the main hall when they are separated by the firedoor, some others measure the audience by closing the scene curtains [96].

The second unresolved point concerns the measure of spaciousness. Indeed, the result of spatial measurement depends on the technologies used in the measurements: different microphones can 
provide different results [153]. Moreover, the spaciousness varies considerably if it measured in the center of the stalls, or near the side walls; if the receiver is in the boxes, it may vary if it is placed close to the edge or inside the box. Spatial measurements [154,155] could become a helpful tool to resolve this ambiguity [156].

Table 4. Surveyed Italian-style opera houses built outside Italy.

\begin{tabular}{llcc}
\hline Ref. & Theatre(s) & Year & Country \\
\hline$[18]$ & Bayreuth Markgräfliches & 1750 & Germany \\
{$[18]$} & L'Opéra Royal Versailles & 1770 & France \\
{$[157]$} & Grand Theatre, Bordeaux & 1780 & France \\
{$[158]$} & S. Carlos, Lisbon & 1793 & Portugal \\
{$[159]$} & Palace Theatre, Archangelskoje & 1818 & Russia \\
{$[160]$} & Bolshoi, Moscow & 1825 & Russia \\
{$[161]$} & Teatro Principal, Valencia & 1832 & Spain \\
{$[162]$} & Opera House, Wroclaw & 1841 & Poland \\
{$[158]$} & Donna Maria II , Lisbon & 1846 & Portugal \\
{$[160]$} & Mariinsky, St. Petersburg & 1860 & Russia \\
{$[160]$} & Opera House, Saratov & 1860 & Russia \\
{$[158]$} & Trindade, Lisbon & 1867 & Portugal \\
{$[160]$} & Opera House, Voronezh & 1870 & Russia \\
{$[158]$} & Sá de Miranda, Viana do Castelo & 1879 & Portugal \\
{$[68]$} & Hungarian State Opera House & 1884 & Hungary \\
{$[158]$} & Coliseu dos Recreios, Lisbon & 1890 & Portugal \\
{$[158]$} & Garcia Resende, Evora & 1892 & Portugal \\
{$[158]$} & S. Luiz, Lisbon & 1894 & Portugal \\
{$[158]$} & Viriato, Viseu & 19 th Century & Portugal \\
{$[59,68]$} & Colon, Buenos Aires & 1908 & Argentina \\
{$[163]$} & Grand Theatre, Poznan & 1910 & Poland \\
{$[160]$} & Opera House, Ekaterinburg & 1912 & Russia \\
{$[164]$} & Municipal Theatre, Lima & 1920 & Perú \\
{$[158]$} & S. Joao, Oporto & 1920 & Portugal \\
{$[160]$} & Music Hall, St. Petersburg & 1928 & Russia \\
{$[160]$} & Maliy, St. Petersburg & 1944 & Russia \\
{$[165]$} & Teatro Argentino, La Plata & 1999 & Argentina \\
{$[166]$} & Opera House, Astana & 2013 & Kazakistan \\
\hline & & &
\end{tabular}

The third point concerns the sound strength. This criterion was still rarely measured, according to Tables 2 and 3. Moreover, a theoretical model for sound energy distribution in an opera house is needed. It must take into account the size of aperture, the coupling effect between the two sub-rooms [146,167-170]—the fly tower and the main hall—and the sound source position [129]. Furthermore, due to the subjective relevance of the balance and listener envelopment, the SISO (single-input-single-output) model of sound strength could be extended. An attempt of MIMO (multiple-input-multiple-output) measurements were done in Comunale Theatre in Bologna. A loudspeaker orchestra was adapted for the pit layout, taking into account the loudspeaker directivity and the sound power level of each source [171].

Virtual acoustics can be a useful tool for improving the knowledge of opera houses [172]. Simulated impulse responses allow us to extend the virtual experience of an opera house, including the occupation and other variables, such as the scene configuration. Virtual acoustics allows also to enjoy a no-longer existing space $[91,173]$. While scale model were widely used in the design and analysis of opera houses until recent years $[110,166,174,175]$, numerical simulation of sound field was introduced, in the context of Italian opera houses, during the 1990s [148,176,177]. However, many models have been developed for acoustic consultancies and they are not available on a repository. As a consequence, there is a limited literature on the materials and acoustic peculiarities of Italian opera houses.

Instead of this, the data sharing could provide many benefits. Neal et al. [178] shared measurements, made by a 32-element spherical microphone array, and both omnidirectional and 
a directional sound source, of American and European concert halls. Concerning the opera houses, as of today there are few examples of free-available data. Büttner et al. [125] shared their work on Italian court theatres, including measured and simulated impulse responses. More models were provided by the author's workgroup for Bayreuther Festspielhaus [179], Alighieri Theatre in Ravenna [91], Comunale of Bologna [130]. In the author's hope, this approach could be shared by the scholars' community, in order to increase the knowledge on this complex topic.

\section{About Performers and Music inside of Opera Houses}

\subsection{The Evolution of the Orchestra, and Orchestra Pit}

In the early 17th Century, musicians were hidden behind the stage, as sentenced by G. B.Doni [180]

“Tutta questa moltitudine d'instrumenti [...] rende cosi poco suono, che appena si ode da' più vicini alla scena" (All this multitude of instruments [...] yields so little sound, that can only just be heard from closer to the scene).

Some years later, still in the court-theatre context, Monteverdi placed the musicians in front of the stage [181]. In the Venetian public theatre with boxes, the orchestra was placed on the stalls floor [182]. This kind of performance needed few musicians (see the St. Moise theatre case in 1720, Table 5) [183]. With the first large-sized theatres, such as the S. Carlo in Naples in 1741 (Table 5), the orchestra increased. Its composition was characterised by a large number of violins and more double-basses than cellos. It should be noted that the sound power level of historical instruments might differ from the one today, and generally historical instruments sound lower. In case of strings it is due to the string materials, in case of woodwinds it depends on the keys. An accurate measurement of these differences was recently made by Weinzierl et al. [184]. Mozart set the balance between the woodwind section, fixing the ratio between flutes, oboes, clarinets, bassons and horns as 2:2:2:2:4 [185]. This ratio was keep during the evolution of opera. Indeed, it was increased to base "at-three"-i.e., three flutes, three oboes, three clarinets and three bassoons-in the Verdian orchestra $[87,88]$ and, then, to base at-four" by the German composers R. Wagner [186] and R. Strauss.

As noted in severals works $[187,188]$, the balance between voice and orchestra plays a predominant role in opera-house acoustics. This is due to the fact that vocal and orchestral signals need different boundary conditions of the sound field, and a well-designed opera house should satisfy both. In an opera, the voice needs more intelligibility and more "focusing" on the soloist $[189,190]$. This means a lower reverberance, and a lower Apparent Source Width, using ISO 3382 subjective categories. In terms of objective criteria, this corresponds to low EDT values and high Inter-Aural Crosscorrelation Coefficient (IACC) values. Instead, music needs more sustain. This means more reverberance and more envelopment, which corresponds to higher EDT values and low IACC values.

The development of the opera house from an acoustic standpoint is essentially aimed at the fulfillment of these needs. In order to assure these conditions the orchestra was placed in the Italian opera house in front of the proscenium. This provides a lot of reflections from the side walls, and scattering from boxes. If the geometry is well-balanced, a very low value of IACC is achieved. Moreover, the energy decay is quite regular, meaning an $E D T / T$ ratio of about one [20]. The singers were placed instead in the fly tower, which provides less reflections due to side curtains, achieving a high IACC value. Moreover, the fly tower is coupled with the main hall through the scenic arch. The effect of this coupling is often a double-slope decay, then an EDT / T ratio is lower than one [191]. 
Table 5. Orchestral configuration during the years. vli: violins-if data are available, they are shown as first parts + second (+ third in Strauss's Salome only); vla: violas; $c l$ : cellos; $d b$ : double-basses; fl: flutes + piccolo; ob: oboes + english horn; cla: clarinets + bass clarinet; bas: bassons + contrabasson; $h o$ : french horns; tp: trumpets + bass trumpets; $t b$ : trombones + cimbasso/Wagner tubas; perc: percussions. Data taken from [87,88,183,185,186].

\begin{tabular}{|c|c|c|c|c|c|c|c|c|c|c|c|c|c|c|c|}
\hline \multirow{2}{*}{ Year } & \multirow{2}{*}{ Opera House } & \multirow{2}{*}{ Performance } & \multicolumn{4}{|c|}{ Strings } & \multicolumn{4}{|c|}{ Woodwinds } & \multicolumn{3}{|c|}{ Brasses } & \multicolumn{2}{|c|}{ Others } \\
\hline & & & vli & vla & cl & $\mathrm{db}$ & fl & ob & cla & bas & ho & tp & $\mathrm{tb}$ & perc & harp \\
\hline 1720 & St. Moise, Venice & & 2 & 1 & 1 & 1 & & 2 & & 2 & 2 & & & & \\
\hline 1741 & San Carlo, Naples & & 38 & 8 & 2 & 4 & & 6 & & 4 & 3 & 2 & & & \\
\hline 1758 & Argentina, Rome & & 16 & 4 & 2 & 3 & & 2 & & 2 & 3 & & & & \\
\hline 1770 & Ducale, Milan & Mozart: Mitridate Re di Ponto & $14+14$ & 6 & 2 & 6 & 2 & 2 & 2 & 2 & 4 & 2 & & yes & \\
\hline 1778 & Comunale, Bologna & & 25 & 8 & 2 & 4 & 2 & 3 & & 2 & 4 & 4 & 4 & yes & \\
\hline 1778 & La Scala, Milan (opening) & Salieri: Europa riconosciuta & 30 & 8 & 5 & 8 & 2 & 3 & 3 & 2 & 4 & 4 & & & \\
\hline 1797 & San Carlo, Naples & & 25 & 4 & 2 & 6 & & 2 & 2 & 4 & 4 & & & & \\
\hline 1818 & Covent Garden, London & & 8 & 1 & 2 & & 1 & 2 & & 2 & 1 & 2 & 1 & yes & \\
\hline 1825 & La Scala, Milan & & 30 & 8 & 6 & 10 & 2 & 2 & 2 & 2 & 2 & 1 & 1 & & \\
\hline 1858 & La Scala, Milan & Verdi: Un ballo in maschera & 28 & 8 & 8 & 8 & $2+1$ & $2+1$ & 3 & 3 & 5 & 3 & $3+1$ & yes & 1 \\
\hline 1876 & Bayreuther Festspielhaus (opening) & Wagner: Ring & $16+16$ & 12 & 12 & 8 & 4 & $3+1$ & $3+1$ & $3+1$ & 8 & 4 & $4+5$ & yes & 4 \\
\hline 1909 & Dresden Oper & Strauss: Elektra & $8+8+8$ & $6+6+6$ & $6+6$ & 8 & $3+1$ & $3+1$ & $5+3$ & $3+1$ & 8 & $6+1$ & $2+3$ & yes & 2 \\
\hline
\end{tabular}


The evolution of the opera during the 19th Century needed more instruments. This was one of the reasons for the original Wagnerian idea of mystic gulf, conceived for the aforementioned Bayreuth Festspielhaus (1872) [57]. However, that was not the only reason: the dramaturgy was increasing in complexity. More complex characters meant more focusing on the soloist. The presence of the orchestra pit increases the envelopment and increases the reverberance ( $E D T / T$ ratio higher than one). The pit provides the perceptual effect of moving the orchestra to the background, while the soloist are still well 'focused' on the stage. This was the reason why some authors compared the Wagnerian opera-and the Festspielhaus - to the birth of Cinema: the soloist is the actor, the orchestra is the background [192]. During the 20th Century, orchestra pits were progressively introduced in Italian theatres $[23,91]$. It should be remarked that orchestra pits require further adjustments, to increase the communication to hall and stage [76,193], and to ensure safe working conditions to musicians [194,195].

Furthermore, the music of the 18th-century opera is mainly based on strings and (few) woodwinds and brasses. In the 19th century the number of woodwinds and brasses increases, as shown by orchestral configuration in Table 5.

\subsection{The Repertory and the Availability of Anechoic Recordings}

The opera-attending experience involves many factors: multi-sensorial, cultural, or emotional. Which kind of anechoic recordings should be available to scholars? A choice criterion could concern the contemporary use of opera houses. Indeed, until the advent of cinema, opera-house seasons mixed new operas and opera from the so-called repertory. Nowadays, besides rare cases, opera seasons are based mostly only on this repertory, which means a selection of compositions of few authors. Table 6 resumes the most represented performances during ten seasons of the last decade, confirming this trend. As an example, the most represented opera (Verdi's Traviata, which has 6843 representations over 1373 productions) alone collects almost the same number collected by all Wagner's operas (7729 representations over 1866 productions). The statistics show that some languages-i.e., the Italian-and some styles-i.e., from late 18 th century to the early 20 th century-are preferred by opera listeners. This can be viewed as an evolutionary selection of the 'software', as the horse-shoe shape was the results of a natural selection of the 'hardware'.

It is interesting to compare the repertory statistics to the anechoic material available for researchers. The earliest anechoic excerpts were recorded in the BBC anechoic chamber [196], by a small orchestra through a single microphone. These recordings had a low dynamics and sounded bit lo-fi, if are compared to today's practices. In 1988 Hidaka et al. [197] recorded a large orchestra in a damped concert hall, surrounding the stage with an acoustically absorptive enclosure. Both previous recording sets include an opera ouverture, but no vocal parts.

In 1998 Farina et al. [198] recorded three excerpts-two arias and a Romanza-for soprano and accompanying piano. Patÿnen et al. [199] recorded symphonic and opera music by using a 22 microphone array. Several musicians and a soloist recorded individually an aria from Mozart's Don Giovanni. Speech excerpts were recorded by the TU-Berlin group $[125,200]$. In more recent years, other opera excerpts were recorded using the Patÿnen-Vigeánt workflow [201], taking into account the statistics of one-year representations in the most important opera houses [202].

Table 7 collects the previously released anechoic recordings. 
Table 6. Statistics of most represented performances in the decade 2010-2019. In the upper table, the ten most represented composer are sort, then are also shown the most represented Czech composer (Janaceck), the most represented composers of 18th century (Gluck, after Mozart), 17th century (Purcell), and 16th century (Monteverdi). In the lower table, the ten most represented operas are sort, and also shown are the two most represented German operas written by Wagner and Mozart, and the most represented operas in Czech and Russian, which are, respectively, Dvorak's Rusalka and Tchaikovsky's Pikovaya Dama. Data from operabase.com.

\begin{tabular}{|c|c|c|c|c|}
\hline \multicolumn{5}{|c|}{ By Composer/period } \\
\hline Composer & Nationality & Century & Performances & Productions \\
\hline Verdi & Italian & 19th & 27,194 & 5911 \\
\hline Puccini & Italian & 19-20th & 20,297 & 3805 \\
\hline Mozart & Austrian & 18th & 19,860 & 4207 \\
\hline Rossini & Italian & 19th & 8674 & 1898 \\
\hline Donizetti & Italian & 19th & 7716 & 1756 \\
\hline Wagner & German & 19th & 7229 & 1866 \\
\hline Bizet & French & 19th & 6517 & 1303 \\
\hline Tchaikovsky & Russian & 19th & 4314 & 1041 \\
\hline R. Strauss & German & 20th & 3970 & 832 \\
\hline Haendel & German/English & 17 th & 2852 & 504 \\
\hline Britten & English & 20th & 2368 & 513 \\
\hline $\begin{array}{l}\ldots \\
\text { Janacek }\end{array}$ & Czech & 19-20th & 2071 & 423 \\
\hline ... & German & 18th & 1435 & 298 \\
\hline Purcell & English & 17 th & 1102 & 280 \\
\hline Monteverdi & Italian & 16-17th & 981 & 250 \\
\hline \multicolumn{5}{|c|}{ By Opera/language } \\
\hline Composer & Title & Language & Performances & Productions \\
\hline Verdi & La traviata & Italian & 6843 & 1373 \\
\hline Mozart & Die Zauberflöte & $\begin{array}{l}\text { German } \\
\text { (Singspiel) }\end{array}$ & 5839 & 900 \\
\hline Bizet & Carmen & French & 5728 & 1110 \\
\hline Puccini & La boheme & Italian & 5316 & 1005 \\
\hline Puccini & Tosca & Italian & 4611 & 989 \\
\hline Rossini & Il barbiere di Siviglia & Italian & 4236 & 918 \\
\hline Puccini & Madama Butterfly & Italian & 4230 & 929 \\
\hline Mozart & Le nozze di Figaro & Italian & 4143 & 815 \\
\hline Verdi & Rigoletto & Italian & 3952 & 866 \\
\hline Mozart & Don Giovanni & Italian & 3949 & 755 \\
\hline Wagner & Der fliegende Holländer & German & 1593 & 332 \\
\hline Mozart & Die Entführung aus dem Serail & German & 1413 & 269 \\
\hline Dvorak & Rusalka & Czech & 1133 & 193 \\
\hline $\begin{array}{l}\ldots \\
\text { Tchaikovsky }\end{array}$ & Pikovaya Dama & Russian & 816 & 209 \\
\hline
\end{tabular}


Table 7. Previously-released anechoic recordings of opera excerpts. "Solo" means that performer(s) was (were) recorded each-at-time, "Ensemble" means that performers were recorded together. "Multi-Tracks" means that recordings are available as multiple tracks with individual instruments/voices.

\begin{tabular}{|c|c|c|c|c|c|}
\hline Ref. & Year & Type & Location & Music Materials & Multi-Tracks \\
\hline [196] & 1969 & ensemble & $\mathrm{BBC}$ & Wagner: Siegfried Idyll & no \\
\hline [197] & 1988 & ensemble & Osaka & $\begin{array}{l}\text { Mozart, Le Nozze De Figaro (Ouverture) } \\
\text { Glinka: Ruslan And Lyudmila (Ouverture) } \\
\text { Verdi: La Traviata (Preludio) }\end{array}$ & no \\
\hline [198] & 1998 & solo ${ }^{1}$ & Parma & $\begin{array}{l}\text { Haendel: "Lascia Ch'io Pianga" from Almira } \\
\text { Tosti: "Ricordi ancora il di' che c'incontrammo" } \\
\text { Mozart: "In uomini, in soldati" from Cosi' Fan Tutte }\end{array}$ & yes \\
\hline [199] & 2008 & solo & Aalto & Mozart: "Mi tradí quell'alma ingrata" from Don Giovanni & yes \\
\hline$[5,125,200]$ & 2015-2019 & solo & TU-Berlin & $\begin{array}{l}\text { Speech from Sofocle's Edipo tiranno } \\
\text { Speech from Cicero's Catiline Oration }\end{array}$ & (yes) \\
\hline$[201,202]$ & $2016-2020$ & solo & Bologna & $\begin{array}{l}\text { Donizetti: “O mio Paride vezzoso" from L'elisir d'amore } \\
\text { Verdi: “Di tale amor che dirsi" from Il trovatore } \\
\text { Puccini: "O mio babbino caro" from Gianni Schicchi }\end{array}$ & yes \\
\hline
\end{tabular}

${ }^{1}$ The orchestral parts were perfomed by a piano accompaniment. 


\section{Final Considerations}

Acoustic concerns were taken into account during the development of the form of the Italian-style opera house. This is the reason why the historical context and the relative technical literature were widely reviewed. Moreover, cultural instances take a relevant place in the acoustic analysis of opera houses.

Many opera houses were surveyed in the past. The results of these measurement campaigns were shared mostly within the Italian acoustic community. However, these contributions led to important results, the most relevant of which is the recognition of opera house acoustics as an intangible cultural heritage.

The cultural background of opera houses was discussed in the present work by several points of view. In the author's hope, this review could fill some gaps, pushing forward the emerging approaches in this research fields.

Funding: This research received no external funding.

Acknowledgments: The author gratefully acknowledge Alessia Milo, who provided useful comments and revisions of the text. Thanks go to Massimo Garai, who helped the author in the final proof reading. Finally, the author wish to thank Nicola Prodi for sharing his experience and material.

Conflicts of Interest: The author declares no conflict of interest.

\section{Abbreviations}

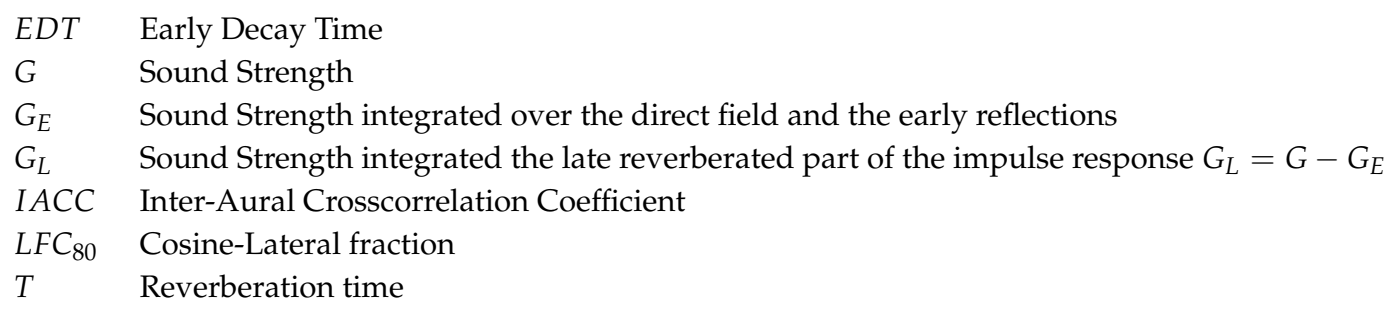

\section{References}

1. Barbieri, P. The state of architectural acoustics in the late renaissance. In Architettura e Musica Nella Venezia del Rinascimento; Howard, D., Moretti, L., Eds.; B. Mondadori: Milan, Italy, 2006.

2. Sanvito, P.; Weinzierl, S. The Acoustics of the Teatro Olimpico in Vicenza. Odeo Olimp. 2013, 23, 463-492. (In Italian)

3. Scamozzi, V. L'idea Della Architettura Universale (About of Universal Architecture); Expensis Auctoris: Venezia, Italy, 1615. (In Italian)

4. Prodi, N.; Pompoli, R. The acoustics of three Italian historical theatres: The early days of modern performance spaces. In Proceedings of the Tecniacustica 2000, Madrid, Spain, 16-20 October 2000.

5. Weinzierl, S.; Sanvito, P.; Schultz, F.; Büttner, C. The acoustics of Renaissance Theatres in Italy. Acta Acust. United Acust. 2015, 101, 632-641. [CrossRef]

6. Torello-Hill, G. The exegesis of Vitruvius and the creation of theatrical spaces in Renaissance Ferrara. Renaiss. Stud. 2014, 29, 227-246. [CrossRef]

7. Girón, S.; Álvarez-Corbacho, A.; Zamarreno, T. Exploring the Acoustics of Ancient Open-Air Theatres. Arch. Acoust. 2020, 45, 181-208. [CrossRef]

8. Bondin, N. Teatro Antico. Ragionamento Sopra la Forma e la Struttura (Ancient Theatre. Reasoning on Form and Structure); (n.p.): Venezia, Italy, 1746. (In Italian)

9. Damun, J. Prospectus du Noveau Theatre Tracé sur les Principes des Grecs et des Romains (Project of a New Theatre Based on Greek and Roman Principles); Lambert: Paris, France, 1772. (In French)

10. Johnson, E.J. Inventing the Opera House: Theater Architecture in Renaissance and Baroque Italy; Cambridge University Press: Cambridge, UK; New York, NY, USA, 2018.

11. Jeon, J.Y.; Kim, Y.H.; Cabrera, D.; Bassett, J. The effect of visual and auditory cues on seat preference in an opera theater. J. Acoust. Soc. Am. 2008, 123, 4272-4282. [CrossRef] 
12. Glixon, B.; Glixon, J. Inventing the Business of Opera. The Impresario and His Work in Seventeenth-Century; Oxford University Press: Oxford, UK, 2006.

13. Bianconi, L.; Walker, T. Production, consumption and political function of seventeenth-century Italian opera. Early Music Hist. 1984, 4, 209-296. [CrossRef]

14. Rosand, E. Opera in Seventeenth-Century Venice: The Creation of a Genre; University of California Press: Berkley, CA, USA, 2007.

15. Bordone, C.; Sacerdote, G. Acoustic problems of boxes of opera houses. In Proceedings of the 2nd International Conference on Acoustics and Musical Research (CIARM95), Ferrara, Italy, 19-21 May 1995; pp. 245-250. (In Italian)

16. Ivanovich, C. Memorie Teatrali di Venezia (Theatrical memories of Venice); N. Pezzana: Venezia, Italy, 1688.

17. Galli Bibiena, F. L'architettura Civile Preparata su la Geometria e Ridotta alle Prospettive (Civil Architecture: Geometry and Perspective); Paolo Monti: Parma, Italy, 1711. (In Italian)

18. Bassuet, A. Acoustics of a selection of famous 18th-Century opera houses: Versailles, Markgräfliches, Drottningholm, Schweitzingen. J. Acoust. Soc. Am. 2008, 123, 3192. [CrossRef]

19. Cervellati, P.L. II Rossini di Lugo: Sul Restauro di un Celebre Teatro (The Rossini in Lugo: On the Restoration of a Famous Theatre); Nuova Alfa Editoriale: Bologna, Italy, 1986. (In Italian)

20. Garai, M.; Morandi, F.; D'Orazio, D.; De Cesaris, S.; Loreti, L. Acoustic measurements in eleven Italian opera houses: Correlations between room criteria and considerations on the local evolution of a typology. Build. Environ. 2015, 94, 900-912. [CrossRef]

21. Cocchi, A.; Garai, M.; Tavernelli, C. Boxes and sound quality in an Italian opera house. J. Sound Vib. 2000, 232, 171-191. [CrossRef]

22. Tronchin, L.; Shimokura, R.; Tarabusi, V. Spatial sound characteristics in the Theatre Comunale in Bologna, Italy. In Proceedings of the 9th Western Pacific Acoustics Conference, Seoul, Korea, 26-28 June 2006.

23. D'Orazio, D.; Fratoni, G.; Rovigatti, A.; Garai, M. A virtual orchestra to qualify the acoustics of historical opera houses. Build. Acoust. 2020. [CrossRef]

24. Giordano, L. The "Teatro dei Quattro Cavalieri" and the work of A. Galli Bibiena in Pavia. Bollettino D'arte 1975, 60, 88-102. (In Italian)

25. Magrini, A.; Ricciardi, P. Acoustic characterization of the Teatro Sociale di Como e del Teatro Fraschini. In Proceedings of the Opera houses of the Unity of Italy, Venice, Italy, 23 November 2011. (In Italian)

26. Iannace, G.; Maffei, L. Acoustic characterization of the Teatro Mercadante. In Proceedings of the Opera Houses of the Unity of Italy, Venice, Italy, 23 November 2011. (In Italian)

27. D'Orazio, D.; Nannini, S. Towards Italian Opera Houses: A review of acoustic design in pre-Sabine scholars. Acoustics 2019, 1, 252-280. [CrossRef]

28. Carini Motta, F. Treaty about the Structure of the Theatres and of the Scenes; Giavazzi: Guastalla, Italy, 1676; republished in Il Polifilo: Milano, Italy, 1972. (In Italian)

29. Algarotti, F. Saggio Sopra L'Opera in Musica (Essay on Opera), 2nd ed.; Marco Coltellini: Livorno, Italy, 1764. (In Italian)

30. Riccati, G. Della Costruzione De' Teatri Secondo il Costume D'Italia: Vale a Dire Divisi in Piccole Logge (About the Construction of Theatres According to the Italian Style, i.e., with Small Boxes); Remondini from Venice: Bassano, Italy, 1790. (In Italian)

31. Memmo, A. Semplici Lumi Tendenti a Render Cauti I Soli Interessati nel Teatro da Erigersi Nella Parocchia di S Fantino in Venezia [...] (Simple Hints for Those Who Are Interested in the Theatre to Build in the Parish of S. Fantino in Venice); (n.p.): Venice, Italy, 1790. (In Italian)

32. Patte, P. Essai sur L'architecture Théatrale, ou, De L'ordonnance la Plus Avantageuse à Une Salle de Spectacles, Relativement aux Principes de L'optique et de L'acoustique: Avec un Examen des Principaux Téatres de l'Europe, et une Analyse des écrits les plus Importans sur Cette Matiere (Essay on Theatre Architecture, or on the Most Advantageous Design of a Performance Hall, and an Analysis of the Most Important Writings on This Topic); Moutard: Paris, France, 1782. (In French)

33. Morelli, C. Pianta e Spaccato del Nuovo Teatro d'Imola (Plan and Section of the New Theatre of Imola); Casaletti: Roma, Italy, 1780. (In Italian)

34. Braham, A. The Architecture of the French Enlightenment; Thames and Hudson: London, UK, 1980. 
35. Arnaldi, E. Idea di un Teatro Nelle Principali Sue Parti Simile A'teatri Antichi All'uso Moderno Accomodato (Idea of a Theatre in Its Principal Parts Similar to Ancient Theatres Arranged for the Modern Use); Veronese: Vicenza, Italy, 1762. (In Italian)

36. Milizia, F. Trattato Completo, Formale e Materiale del Teatro (About the Theatre); Stamperia Pasquali: Venezia, Italy, 1794. (In Italian)

37. Ledoux, C.N. L'architecture Considerée sour le Rapport de l'Art, des Moeurs et de la Legislation ... (The Architecture Considered through the Connections with Art, Traditions and Law); Perroneau: Paris, France, 1804. (In French)

38. Boullée, E.L. Architecture, Essai sur l'art (Architecture, Essay on Art); Rosenau, H., Ed.; Tiranti: London, UK, 1953. (In French)

39. Barbieri, P.; Tronchin, L. L'impostazione acustica dei teatri nei progetti del primo neoclassicismo Italiano (1762-1772), (The Acoustical Structure of Theatres in the First Italian Neoclassical Projects). In Francesco Milizia e il Teatro del suo Tempo Architettura, Musica, Scena, Acustica; Collana Studi e Ricerche n. 2; Russo: Trento, Italy, 2011; pp. 137-161, ISBN 978-88-8443-396-1. (In Italian)

40. Beccega, T. Sull'architettura Greco-Romana Applicata Alla Costruzione del Teatro Moderno Italiano e Sulle Macchine Teatrali (On the Application of the Graeco-Roman Architecture to the Construction of the Modern Italian Theatre and to the Theatrical Machines); Alvisopoli: Venezia, Italy, 1817. (In Italian)

41. Tronchin, L. Francesco Milizia (1725-1798) and the Acoustics of his Teatro Ideale (1773). Acta Acust. United Acust. 2013, 99, 91-97. [CrossRef]

42. Forsyth, M. Buildings for Music; The Press Syndicate: Cambridge, UK, 1985.

43. Niccolini, A. Alcune Idee Sulla Risonanza del Teatro (Some Ideas on the Resonance of the Theatre); Masi: Napoli, Italy, 1816. (In Italian)

44. Prodi, N.; Pompoli, R.; Martellotta, F.; Sato, S. Acoustics of Italian historical opera houses. J. Acoust. Soc. Am. 2015, 138, 769-781. [CrossRef] [PubMed]

45. Meduna, T.; Meduna, G. Il Teatro La Fenice in Venezia... (On the La Fenice Theatre... ); Antonelli: Venezia, Italy, 1849. (In Italian)

46. de Cesare, F. La Scienza dell'Architettura Applicata alla Costruzione, alla Distribuzione, alla Decorazione Degli Edifici Civili (The Science of Architecture on the Construction, Distribution and Decoration of Civil Buildings); Pellizzone: Napoli, Italy, 1885. (In Italian)

47. Favaro, A. L'Acustica Applicata alla Costruzione delle sale per Spettacoli e Pubbliche Adunanze (Acoustics Applied to the Construction of Performance Spaces and Public Meetings); Camilla e Bertolero: Torino, Italy, 1882. (In Italian)

48. Basile, G.B.F. Sulla costruzione del Teatro Massimo Vittorio Emanuele (On the Construction of Teatro Massimo Vittorio Emanuele); Tip. Dello Statuto: Palermo, Italy, 1883. (In Italian)

49. Newton, J.P. Room Acoustics Measurements at the Royal Opera House, London. In Proceedings of the 17th International Congress on Acoustics (ICA), Rome, Italy, 2-7 September 2001.

50. Saunders, G. Treatise on Theaters; I. and J. Taylor: London, UK, 1790.

51. Postma, B. A history of the use of time intervals after the direct sound in concert hall design before the reverberation formula of Sabine became generally accepted. Build. Acoust. 2013, 20, 157-176. [CrossRef]

52. Postma, B.N.; Jouan, S.; Katz, B.F. Pre-Sabine room acoustic design guidelines based on human voice directivity. J. Acoust. Soc. Am. 2018, 143, 2428-2437. [CrossRef]

53. Postma, B.N.; Katz, B.F. Pre-Sabine room acoustic assumptions on reverberation and their influence on room acoustic design. J. Acoust. Soc. Am. 2020, 147, 2478-2487. [CrossRef] [PubMed]

54. Bagenal, H.; Wood, A. Planning for Good Acoustics; Methuen \& Co.: London, UK, 1931.

55. Garnier, C. Le Thêâtre (The Theatre); Librairie Hachette: Paris, France, 1871; Chapitre IX.

56. Müller, K. Festspielhaus Bayreuth-The unique acoustic situation. J. Acoust. Soc. Am. 1999, 105, 929. [CrossRef]

57. D'Orazio, D.; De Cesaris, S.; Morandi, F.; Garai, M. The aesthetics of the Bayreuth Festspielhaus explained by means of acoustic measurements and simulations. J. Cult. Herit. 2018, 34, 151-158. [CrossRef]

58. Link, D. The National Court Theater in Mozart's Vienna: Sources and Documents 1783-1792; Oxford University Press: New York, NY, USA, 1998,

59. Basso, G. Acoustical evaluation of the Teatro Colón of Buenos Aires. Proc. Meet. Acoust. 2017, 30, 015014.

60. Sabine, W.C. Theater Acoustics. Am. Archit. 1913, 104, 257.

61. Burris-Meyer, H. Sound in the theater. J. Acoust. Soc. Am. 1940, 11, 346. [CrossRef] 
62. Hutchins-Viroux, R. Opera and Society in the English-speaking World. The American Opera Boom of the 1950s and 1960s: History and Stylistic Analysis. Lit. Hist. Ideas Images Soc. Engl.-Speak. World 2004, 2, 145-163.

63. Jordan, V.L. Acoustical design considerations of the Sydney Opera House. J. Proc. R. Soc. N. S. W. 1973, 106, 33-53.

64. Beranek, L.L. Music, Acoustics \& Architecture; John Wiley \& Sons: New York, NY, USA, 1962.

65. Beranek, L.L. Riding the Waves; The MIT Press: Cambridge, MA, USA, 2008.

66. Beranek, L.L.; Hidaka, T.; Masuda, S. Acoustical design of the opera house of the New National Theatre, Tokyo, Japan. J. Acoust. Soc. Am. 2000, 107, 355-367. [CrossRef] [PubMed]

67. Beranek, L.L. Concert and Opera Halls. How They Sound; American Institute of Physics: Woodbury, NY, USA, 1996.

68. Hidaka, T.; Beranek, L.L. Objective and subjective evaluations of twenty-three opera houses in Europe, Japan, and the Americas. J. Acoust. Soc. Am. 2000, 107, 368-383. [CrossRef]

69. Fausti, P.; Pompoli, R.; Prodi, N. Acoustics of opera houses: A cultural heritage. J. Acoust. Soc. Am. 1999, 105, 929. [CrossRef]

70. Farina, A.; Ayalon, R. Recording concert hall acoustics for posterity. In Proceedings of the 24th AES Conference on Multichannel Audio, Banff, AB, Canada, 26-28 June 2003.

71. Prodi, N.; Pompoli, R. Acoustics in the restoration of Italian historical opera houses: A review. J. Cult. Herit. 2016, 21, 915-921. [CrossRef]

72. Prodi, N. From tangible to intangible heritage inside Italian historical opera houses. Heritage 2019, 2, 826-835. [CrossRef]

73. Farina, A. Acoustic quality of theatres: Correlations between experimental measures and subjective evaluations. Appl. Acoust. 2001, 62, 899-916. [CrossRef]

74. Iannace, G.; Ianniello, C.; Maffei, L.; Romano, R. Objective measurement of the listening condition in the old Italian opera house Teatro di San Carlo. J. Sound Vib. 2000, 232, 239-249. [CrossRef]

75. Dragonetti, R.; Ianniello, C.; Mercogliano, F.; Romano, R.A. The Teatro di San Carlo in Naples and its smaller clone Teatro Verdi in Salerno. In Proceedings of the Acoustics 08, Paris, France, 30 June-4 July 2008; pp. 1367-1372.

76. Facondini, M.; Bignozzi, L. Variable sound orchestra pit for the "Teatro Comunale" of Bologna. In Proceedings of the 17th International Congress on Acoustics (ICA), Rome, Italy, 2-7 September 2001.

77. Tronchin, L.; Tarabusi, V. Acoustic characterization of the Teatro Comunale in Bologna and the Teatro Bonci in Cesena. In Proceedings of the Opera Houses of the Unity of Italy, Venice, Italy, 23 November 2011. (In Italian)

78. Arau, H. Renovating Teatro alla Scala Milano for the 21st century, Part I and II. J. Acoust. Soc. Am. 2005, 117, 2522. [CrossRef]

79. Farina, A.; Capra, A.; Armelloni, E.; Varani, C.; Amendola, A. Acoustic survey of the Teatro alla Scala in Milan. In Proceedings of the Opera Houses of the Unity of Italy, Venice, Italy, 23 November 2011. (In Italian)

80. Tronchin, L.; Farina, A. Acoustics of the former Teatro La Fenice in Venice. J. Audio Eng. Soc. 1997, 45, 1051-1062.

81. Ceniccola, G. Architetture in Scena. Teatri Storici in Campania tra XVIII e XX Secolo: Conoscenza e Nodi Critici nel Progetto di Conservazione (Performance Architecture. Historical Theatres in Campania between 18th and 20th Century: Knowledge and Criticalities in the Conservation Project). Ph.D. Thesis, University of Naples "Federico II", Naples, Italy, 2011. (In Italian)

82. Quagliarini, E. Costruzioni in Legno nei Teatri All'Italiana del '700 e '800: Il Patrimonio Nascosto Dell'architettura Teatrale Marchigiana (Wooden Buildings in Italian Historical Opera Houses: The Hidden Heritage of Theatrical Architecture); Allinea: Firenze, Italy, 2008. (In Italian)

83. Martellotta, F. Acoustics of Apulian Historical Theatres: Further developments of the research. In Proceedings of the Opera Houses of the Unity of Italy, Venice, Italy, 23 November 2011. (In Italian)

84. Zecchin, R.; Di Bella, A.; Boniotto, E.; Boscolo, S.; Bovo, M.E.; Granzotto, N.; Rinaldi, C. Survey on opera houses in Triveneto: Analysis of the main acoustic parameters. In Proceedings of the 33rd National Meeting of Italian Acoustic Society, Ischia, Italy, 10-12 May 2006. (In Italian)

85. Iannace, G.; Ianniello, C.; Maffei, L.; Romano, R. Acoustics measurements in the Teatro dell'Opera in Rome. In Proceedings of the 17th International Congress on Acoustics (ICA), Rome, Italy, 2-7 September 2001. 
86. Cammarata, G.; Fichera, A.; Marletta, L. Indici di qualità acustica del Teatro Bellini di Catania (Acoustical quality indexes of the Bellini Theatre in Catania). In Proceedings of the 27th National Meeting of Italian Acoustic Society, Padua, Italy, 31 March-2 April 1993. (In Italian)

87. Harwood, G.W. Verdi's Reform of the Italian Opera Orchestra. 19th-Century Music 1986, 10, $108-134$. [CrossRef]

88. Giordani, E.; Salvarani, M. Orchestral staff in 19th century Opera Houses, Introductory Issues for a Psycho-Acoustic Evaluation; Studi Verdiani 16; Mattioli 1885: Parma, Italy, 2002. (In Italian)

89. Bortolotti, L.; Masetti, L. Teatri Storici. Dal Restauro allo Spettacolo (Historical Theatres. From Renovation to Performance); Nardini: Fiesole, Italy, 1977. (In Italian)

90. Silingardi, V.; Rinaldi, C.; Granzotto, N.; Barbaresi, L.; di Bella, A. A restoration based on the result of a public debate: The case of Civic Theatre of Schio. Riv. Ital. Acust. 2017, 41, 1-14.

91. D'Orazio, D.; Rovigatti, A.; Garai, M. The Proscenium of Opera Houses as a disappeared intangible heritage: A virtual reconstruction of the 1840s original design of the Alighieri Theatre in Ravenna. Acoustics 2019, 1, 694-710. [CrossRef]

92. Cocchi, A.; Farina, A.; Tronchin, L. Computer assisted methods and acoustic quality: Recent restoration case histories. In Proceedings of the MCHA95, Kirishima, Japan, 15-18 May 1995.

93. Cocchi, A.; Consumi, M.C.; Shimokura, R. Considerations about the acoustic properties of Teatro Nuovo in Spoleto after the restoration works. In Proceedings of the Acoustics 08, Paris, France, 30 June-4 July 2008; pp. 1391-1394.

94. Tronchin, L. The design of acoustical enhancements and diffusion in the opera house of Treviso, Italy. In Proceedings of the 6th International Conference on Auditorium Acoustics, IOA, Copenhagen, Denmark, 5-7 May 2006.

95. Pisani, R.; Duretto, F. The restoration and the acoustic issues of historical theatres. In Proceedings of the 27th National Meeting of Italian Acoustic Society, Genua, Italy, 26-28 May 1999. (In Italian)

96. Facondini, M. Acoustic restoration of the Teatro Comunale Gioacchino Rossini in Pesaro. In Proceedings of the 17th International Congress on Acoustics (ICA), Rome, Italy, 2-7 September 2001.

97. Fausti, P.; Prodi, N. On the testing of renovations inside historical opera houses. J. Sound Vib. 2002, 258, 563-575. [CrossRef]

98. Strada, M.; Pompoli, R. Acoustic program in the competition for the reconstruction of the "La Fenice" opera house after the fire of 29 January 1996. J. Sound Vib. 2000, 232, 9-15 [CrossRef]

99. Cocchi, A.; Garai, M.; Tronchin, L. Influenza di cavità risonanti poste sotto la fossa orchestrale: Il caso del teatro Alighieri di Ravenna (The Influence of Resonating Cavities under the Orchestra Pit: The Case of the Alighieri Theatre in Ravenna). In Teatri Storici. Dal Restauro Allo Spettacolo; Nardini Editore: Firenze, Italy, 1997; pp. 67-84, 135-153. (In Italian)

100. Cancellieri, G.; Turrini, A. The Phantom of Modern Opera: How Economics and Politics Affect the Programming Strategies of Opera Houses. Int. J. Arts Manag. 2016, 18, 25-36.

101. Bernardini, G. Application to a Case Study: Fire Safety in Historical Theaters. In Fire Safety of Historical Buildings; Springer Briefs in Applied Sciences and Technology; Springer: Berlin, Germany, 2017.

102. Sacerdote, G.G.; Pisani, R. The new Teatro Regio of Torino. Acustica 1975, 32, 138-146

103. Guglielmino, D. Il Regio e la Sua Acustica (The Regio Opera House and Its Acoustics). Master's Thesis, Politecnico di Torino, Turin, Italy, 2007.

104. Di Bella, A.; Zecchin, R. Acoustic characteristics of Teatro La Fenice. In Proceedings of the Opera Houses of the Unity of Italy, Venice, Italy, 23 November 2011. (In Italian)

105. Facondini, M.; Ponteggia, D. Acoustics of the Restored Petruzzelli Theater. In Proceedings of the 128th AES Convention, London, UK, 22-25 May 2010; Convention Paper 8024.

106. Cocchi, A.; Ando, Y. The Le Muse Theatre in Ancona: Recent Developments. In Proceedings of the Auditorium Acoustics, London, UK, 19-21 July 2002.

107. Tronchin, L. The reconstruction of the Teatro Galli in Rimini: The acoustic design. In Proceedings of the International Symposium on Room Acoustics (ISRA), Melbourne, Australia, 29-31 August 2010.

108. Tronchin, L.; Facondini, M.; D'Orazio, D.; Farnetani, A. The acoustic quality of the Teatro Galli in Rimini after the restoration. In Proceedings of the46th National Meeting of Italian Acoustic Society, Pesaro, Italy, 29-31 May 2019. (In Italian) 
109. Pompoli, R.; Farina, A.; Fausti, P. The acoustics of the Nuovo Teatro Comunale in Cagliari International. In Proceedings of the Institute of Acoustics, London, UK, 10-12 February 1995.

110. Commins, D.; Pompoli, R.; Farina, A.; Fausti, P.; Prodi, N. Acoustics of Teatro degli Arcimboldi in Milano design, computer and scale models, details, results. In Proceedings of the Institute of Acoustics (IOA2002), London, UK, 19-21 July 2002.

111. Reinhold, J.; Conta, S. The acoustics of the new opera house in Florence: Innovative choices in a quasi-classical theatre. In Proceedings of the 39th National Meeting of Italian Acoustic Society, Rome, Italy, 4-6 July 2012. (In Italian)

112. Faggiani, D. Sul tempo di circonsonanza delle sale di spettacolo (About the reverberation time of performance halls). Atti del Regio Istituto Lombardo 1936, 16-20, 1-8.

113. Faggiani, D. La reazione del palcoscenico sulla dinamica sonora delle sale (The effects of stage acoustic response on the sound of the halls). Il Politecnico 1937, 85, 3-10.

114. Cocchi, A. The Giuseppe Verdi theatre in Busseto. In Proceedings of the 1st National Meeting of Italian Acoustic Society, Roma, Italy, 1 May 1973; pp. 9-23. (In Italian)

115. Cocchi, A. Riflessioni in merito all'acustica dei teatri (Meditations about the acoustics of theaters). Riv. Ital. Acust. 1984, 8, 69. (In Italian)

116. Ianniello, C. The acoustics of the Italian-style Opera House. In Proceedings of the 17th International Congress on Acoustics (ICA), Rome, Italy, 2-7 September 2001.

117. Ianniello, C. Some notes on historical theatres for opera. Riv. Ital. Acust. 2002, 26, 45-62. (In Italian)

118. Cammarata, G.; Fichera, A.; Rizzo, G. Analysis of objective acoustic parameters in some Italian theatres (influence of the diffuse reflection coefficient). In Proceedings of the 27th National Meeting of Italian Acoustic Society, Genoa, Italy, 26-28 May 1999; pp. 78-81. (In Italian)

119. Prodi, N.; Pompoli, R. Guidelines for acoustic measurements inside historical opera houses. Procedures and validation J. Sound Vib. 2000, 232, 281-301.

120. Fausti, P.; Farina, A. Acoustic measurements in opera houses: A comparison between different techniques and equipment. J. Sound Vib. 2000, 232, 213-229. [CrossRef]

121. D'Orazio, D.; De Cesaris, S.; Guidorzi, P.; Barbaresi, L.; Garai, M.; Magalotti, R. Room acoustic measurements using a high SPL dodecahedron. In Proceedings of the 140th AES Convention, Paris, France, 4-7 June 2016.

122. Papadakis, N.M.; Stavroulakis, G.E. Review of Acoustic Sources Alternatives to a Dodecahedron Speaker. Appl. Sci. 2019, 9, 3705. [CrossRef]

123. Pompoli, R.; Prodi, N. A study on balance inside an historical opera house. In Proceedings of the 17th International Congress on Acoustics (ICA), Rome, Italy, 2-7 September 2001.

124. Pelorson, X.; Vian, J.P.; Polack, J.D. On the variability of room acoustical parameters: Reproducibility and statistical validity. Appl. Acoust. 1992, 37, 175-198. [CrossRef]

125. Büttner, C.; Schultz, F.; Weinzierl, S. Room Acoustical Measurements and Simulations of Italian Renaissance Theatres. 2014. Available online: http:/ / dx.doi.org/10.14279/depositonce-32.2 (accessed on 3 July 2020).

126. Strada, M.; Romagnoni, P.; Carbonari, A. Sound level measurements and assessments on internal acoustics in a historic Venetian theater: The Malibran. In Proceedings of the National Meeting of Italian Acoustic Society, Venice, Italy, 5-7 May 2004. (In Italian)

127. Cammarata, G.; Fichera, A.; Pagano, A.; Rizzo, G. Acoustical prediction in some Italian theatres. Acoust. Res. Lett. Online 2001, 2, 61-66. [CrossRef]

128. Bonsi, D.; Stanzial, D. Using orchestra shell for acoustic optimization of the Teatro Accademico in Castelfranco Veneto. In Proceedings of the 29th National Conference of Italian Acoustic Association, Ferrara, Italy, 12-14 June 2002; pp. 601-604. (In Italian)

129. Garai, M.; De Cesaris, S.; Morandi, F.; D'Orazio, D. Sound energy distribution in Italian opera houses. Proc. Meet. Acoust. 2016, 28, 015019.

130. D'Orazio, D.; Fratoni, G. TCBO CAD and Measured IRs, Mendeley Data. 2019. Available online: http: / / dx.doi.org/10.17632/ggty3v22cx (accessed on 3 July 2020).

131. Iannace, G.; Ianniello, C.; Maffei, L.; Romano, R. The acoustic of the Teatro di Corte Reggia in Caserta. In Proceedings of the 17th International Congress on Acoustics (ICA), Rome, Italy, 2-7 September 2001.

132. Fausti, P.; Pompoli, R. The acoustic of the Comunale Theatre in Ferrara. In Proceedings of the Acoustics of Historical Theatres: A Cultural Heritage, Ferrara, Italy, 4 November 1998; pp. 53-62. (In Italian) 
133. Di Bella, A.; Zecchin, R. Acoustic characteristics of Teatro Verdi in Trieste. In Proceedings of the Opera Houses of the Unity of Italy, Venice, Italy, 23 November 2011. (In Italian)

134. Masoero, M.; Astolfi, A.; Bottalico, P.; Pisani, R. Acoustics of the Teatro Grande in Brescia. In Proceedings of the Opera Houses of the Unity of Italy, Venice, Italy, 23 November 2011. (In Italian)

135. Farina, A.; Capra, A.; Armelloni, E.; Varani, C.; Amendola, A. Acoustic survey of the Teatro Regio in Parma. In Proceedings of the Opera Houses of the Unity of Italy, Venice, Italy, 23 November 2011. (In Italian)

136. Facondini, M. The Sound of the Stage; Il Ponte Vecchio: Cesena, Italy, 1999; ISBN 88-8312-036-1. (In Italian)

137. Mazzarella, L.; Cairoli, M. Petrarca Theatre: A case study to identify the acoustic parameters trends and their sensitivity in a horseshoe shape opera house. Appl. Acoust. 2018, 136, 61-75. [CrossRef]

138. Astolfi, A.; Bortolotto, A.; Filippi, A.; Masoero, M. Acoustical characterisation of small Italian opera house. In Proceedings of the Forum Acusticum, Budapest, Hungary, 29 August-2 September 2005.

139. Lori,V.; Serpilli, F.; Cesini, G.; Costanzo, E.; Montelpare, S.; Mataloni, G. Acoustics survey of some historical opera houses of Abruzzo region. In Proceedings of the 43rd National Meeting of Italian Acoustic Society, Alghero, Italy, 25-27 May 2016. (In Italian)

140. Bartoli, C. Acoustics of theatres and auditoria in the province of Pisa: First results. In Proceedings of the 33rd National Conference of Italian Acoustic Association, Ischia, Italy, 10-12 May 2006; pp. 533-536. (In Italian)

141. Tronchin, L. Acoustical design of diffusing panels in the Theatre Vittorio Emanuele, Messina, Italy. In Proceedings of the Room Acoustics: Design and Science (RADS), Awaji, Japan, 11-13 April 2004.

142. Cirillo, E.; dell'Alba, M.; Martellotta, F. Acoustic survey of historical Apulian theatres. In Proceedings of the 38th National Meeting of Italian Acoustic Society, Rimini, Italy, 8-10 June 2011. (In Italian)

143. Farina, A.; Capra, A.; Armelloni, E.; Varani, C.; Amendola, A. Acoustic survey of the Teatro Valli in Reggio Emilia. In Proceedings of the Opera Houses of the Unity of Italy, Venice, Italy, 23 November 2011. (In Italian)

144. Masoero, M.; Astolfi, A.; Bottalico, P.; Pisani, R. Acoustics of the Teatro Alfieri in Asti. In Proceedings of the Opera Houses of the Unity of Italy, Venice, Italy, 23 November 2011. (In Italian)

145. Iannace, G.; Maffei, L. Acoustic characterization of the Teatro Verdi in Salerno. In Proceedings of the Opera Houses of the Unity of Italy, Venice, Italy, 23 November 2011. (In Italian)

146. D'Orazio, D.; Fratoni, G.; Garai, M. Overhead stage canopies in a coupled volume theatre: Effects on the sound energy distribution and on the secondary reverberation. J. Acoust. Soc. Am. 2019, 146, 2802. [CrossRef]

147. D'Orazio, D. Duse Theatre CAD and Measured IRs, Mendeley Data. 2019. Available online: http://dx.doi. org/10.17632/br9x8hp52m (accessed on 3 July 2020).

148. Tronchin, L.; Farolfi, G. Acoustic design through measurements and computer simulations: The Teatro Comunale of Gradisca d'Isonzo. Riv. Ital. Acust. 1996, 20, 17-27. (In Italian)

149. Tronchin, L.; Tarabusi, V. The acoustic design of the Teatro Eschilo, Gela (Italy). In Proceedings of the International Symposium on Room Acoustics (ISRA), Melbourne, Australia, 29-31 August 2010.

150. Qandil, E.; Ianniello, C.; Iannace, G. The effect of stage scenery on the acoustics of an Italian opera house. In Proceedings of the 17th International Congress on Acoustics (ICA), Rome, Italy, 2-7 September 2001.

151. Jeon, J.Y.; Kim, J.H.; Ryu, J.K. The effects of stage absorption on reverberation times in opera house seating areas. J. Acoust. Soc. Am. 2015, 137, 1099-1107. [CrossRef]

152. Bradley, D.T.; Wang, L.M. The effects of simple coupled volume geometry on the objective and subjective results from nonexponential decay. J. Acoust. Soc. Am. 2005, 118, 1480-1490. [CrossRef]

153. Vigeant, M.C.; Giacomoni, C.B.; Scherma, A.C. Repeatability of spatial measures using figure-of-eight microphones. Appl. Acoust. 2013, 74, 1076-1084. [CrossRef]

154. Farina, A.; Tronchin, L. 3D sound characterisation in theatres employing microphone arrays. Acta Acust. United Acust. 2013, 99, 118-125. [CrossRef]

155. Martellotta, F. On the use of microphone arrays to visualize spatial sound field information. Appl. Acoust. 2013, 74, 987-1000. [CrossRef]

156. Dick, D.A.; Vigeant, M.C. An investigation of listener envelopment utilizing a spherical microphone array and third-order ambisonics reproduction J. Acoust. Soc. Am. 2019, 145, 2795-2809. [CrossRef]

157. Semidor, C.; Barlet, A. Objective and subjective surveys of opera house acoustics: Example of the Grand Theatre de Bordeaux. J. Sound Vib. 2000, 232, 251-261. [CrossRef]

158. Santiago, F. Portuguese Theatres and Concert Halls Acoustics. Master's Thesis, Engineer \& Arquitecture La Salle Arquitectural and Environmental Acoustics Master, Barcelona, Spain, 15 March 2007. 
159. Lannie, M. Acoustics of Gonzago Theatre in the Palace and Park Museum of Archangelskoje. Appl. Acoust. 1993, 40, 347-353. [CrossRef]

160. Lannie, M.; Makrinenko, L. Acoustics of Russian classical opera houses. In Proceedings of the 102nd Audio Engineering Society Convention, Munich, Germany, 22-25 March 1997; Preprint 4427 (D8).

161. Cerdá, S.; Giménez, A.; Romero, J.; Cibrián, R.M.; Miralles, J.L. Room acoustical parameters: A factor analysis approach. Appl. Acoust. 2009, 70, 97-109. [CrossRef]

162. Rudno-Rudziński, K.; Dziechciński, P. Reverberation time of Wrocław opera house after restoration. Arch. Acoust. 2006, 31, 247-252.

163. Sygulska, A. The influence of the stage layout on the acoustics of the auditorium of the Grand Theatre in Poznan. In Proceedings of the Acoustics 08, Paris, France, 29 June-4 July 2008.

164. Dianderas, C.J. Acoustical evalutation of the Municipal Theatre of Lima. Appl. Acoust. 1992, 35, $153-166$. [CrossRef]

165. Baggio, M. Measurements of Teatro Argentino de La Plata. In Acoustical Instruments and Measurements; Universidad Nacional de Tres de Febrero: Buenos Aires, Argentina, 2013.

166. Cairoli, M.; Moretti, E.; Gade, A.C. New opera house in Astana: A recent opportunity to use a room acoustic scale model. Proc. Meet. Acoust. 2013, 19, 015131. [CrossRef]

167. Ermann, M. Coupled Volumes: Aperture size and the double-sloped decay of concert halls. Build. Acoust. 2005, 12, 1-14. [CrossRef]

168. Cappello, D.; Prodi, N.; Pompoli, R. A case history of coupled volumes in an historical opera house. In Proceedings of the ISRA 2007, Seville, Spain, 10-12 September 2007.

169. D'Orazio, D.; Fratoni, G.; Garai, M. Acoustics of a chamber music hall inside a former church by means of sound energy distribution. Can. Acoust. 2017, 45, 7-17.

170. Stanzial, D.; Bonsi, D.; Prodi, N. Measurement of new energetic parameters for the objective characterisation of an opera house. J. Sound Vib. 2000, 232, 193-211. [CrossRef]

171. D'Orazio, D.; Barbaresi, L.; Garai, M. A loudspeaker orchestra for opera houses studies. J. Acoust. Soc. Am. 2017, 141, 3998. [CrossRef]

172. Lokki, T.; Pätynen, J. Applying anechoic recordings in auralization. In Proceedings of the EAA Symposium on Auralization, Espoo, Finland, 15-17 June 2009; pp. 15-17.

173. Fabbri, P.; Farina, A.; Fausti, P.; Pompoli, R. The second life of the Teatro degli Intrepidi by G. B. Aleotti through the new techniques of virtual acoustics. In Proceedings of the 2nd International Conference on Acoustics and Musical Research (CIARM95), Ferrara, Italy, 19-21 May 1995. (In Italian)

174. Cocchi, A.; Farina, A.; Rocco, L. Reliability of scale-model researches: A concert hall case. Appl. Acoust. 1990, 30, 1-13. [CrossRef]

175. Ryu, J.K.; Jeon, J.Y. Subjective and objective evaluations of a scattered sound field in a scale model opera house. J. Acoust. Soc. Am. 2008, 124, 1538-1549. [CrossRef] [PubMed]

176. Cammarata, G.; Fichera, A.; Graziani, S. A Virtual Instrument for the Analysis of Objective Acoustic Parameters. In Proceedings of the 2nd International Conference on Acoustics and Musical Research (CIARM95), Ferrara, Italy, 19-21 May 1995.

177. Farina, A. Aurora listens to the traces of pyramid power. Noise Vibr. Worldw. 1995, 26, 6-9.

178. Neal, M.T.; Vigeant, M.C. A measurement database of US and European concert halls for realistic auralization and study of individual preference. Proc. Inst. Acoust. 2018, 40, 27-38

179. D'Orazio, D. Bayreuth Festspielhaus CAD and Virtual BRIRs, Mendeley Data. 2019. Available online: http:/ / dx.doi.org/10.17632/d85cbd4d6y (accessed on 3 July 2020).

180. Doni, G.B.; Gori, A.F.; Passeri, G.B. Lyra Barbarina Amphichordos: De' Trattati Di Mvsica; Caesar Stamperia Imperiale: Florence, Italy, 1763. (In Italian)

181. Barbieri, P. The acoustics of Italian opera houses and auditoriums. Recercare 1998, 10, 263-328.

182. Bjurstrom, P. Giacomo Torelli and Baroque Stage Design; Almqvist \& Wiksell: Stockholm, Sweden, 1961.

183. Zaslaw, N.; Spitzer, J. The Birth of the Orchestra: History of an Institution; Oxford University Press: New York, NY, USA, 2004.

184. Weinzierl, S.; Lepa, S.; Schultz, F.; Detzner, E.; von Coler, H.; Behler, G. Sound power and timbre as cues for the dynamic strength of orchestral instruments. J. Acoust. Soc. Am. 2018, 144, 1347-1355. [CrossRef] [PubMed] 
185. Halpin, P.W. The Wind Band in Mozart's Opera Orchestra: Origins, Function, and Legacy. Available online: https:/ / opencommons.uconn.edu/dissertations / AAI3265776 (accessed on 3 July 2020).

186. Bebbington, W.A. The Orchestral Conducting Practice of Richard Wagner. Ph.D. Thesis, Musicology, City Univ. of New York, New York, NY, USA, 1984.

187. Prodi, N.; Velecka, S. A scale value for the balance inside an historical opera house. J. Acoust. Soc. Am. 2005, 117, 771-779. [CrossRef]

188. Sato, S.; Prodi, N. On the subjective evaluation of the perceived balance between a singer and a piano inside different theatres. Acta Acust. United Acust. 2009, 95, 532-539. [CrossRef]

189. D'Orazio, D.; De Cesaris, S.; Garai, M. A comparison of methods to compute the "effective duration" of the autocorrelation function and an alternative proposal. J. Acoust. Soc. Am. 2011, 130, 1954-1961. [CrossRef] [PubMed]

190. D'Orazio, D.; Garai, M. The autocorrelation-based analysis as a tool of sound perception in a reverberant field. Riv. Estet. 2017, 66, 133-147. [CrossRef]

191. De Cesaris, S.; Morandi, F.; Loreti, L.; D'Orazio, D.; Garai, M. Notes about the early to late transition in Italian theatres. In Proceedings of the ICSV22, Florence, Italy, 12-16 July 2015.

192. Polack, J.-D.; Retbi, M. Wagner and the Cinema: A Cognitive Approach to the Acoustics of the Bayreuth Festival Theatre. In Proceedings of the Institute of Acoustics, Dublin, Ireland, 20-22 May 2011.

193. Prodi, N.; Pompoli, R.; Parati, L. The acoustics of the municipal theatre in Modena. In Proceedings of the Forum Acusticum 2002, Seville, Spain, 3-7 September 2002.

194. Iannace, G.; Iannello, C.; Maffei, L.; Romano, R. Room acoustic conditions of performers in an old opera house. J. Sound Vib. 2000, 232, 17-26. [CrossRef]

195. D.Lgs. 81/2008 Art. 98 Worker Safety: Guide Lines to Musicians and Perfomances. 2012. Available online: https:/ / www.lavoro.gov.it/documenti-e-norme/studi-e-statistiche/Documents/Testo\%20Unico\% 20sulla\%20Salute\%20e\%20Sicurezza\%20sul\%20Lavoro/Testo-Unico-81-08-Edizione-Giugno\%202016.pdf (accessed on 3 July 2020).

196. Burd, A.N. Non-Reverberant Music for Acoustic Studies; The British Broadcasting Corporation Report No. 1969/17; British Broadcasting Corporation: London, UK, 1969.

197. Hidaka, T.; Kageyama, K.; Masuda, S. Recording of anechoic orchestral music and measurement of its physical characteristics based on the auto-correlation function. Acustica 1988, 67, 68-70.

198. Farina, A.; Bigi, L.; Tronchin, L. Anechoic Recordings. Available online: http://www.angelofarina.it/Public/ Anecoic/ (accessed on 3 July 2020).

199. Pätynen, J.; Pulkki, V.; Lokki, T. Anechoic recording system for symphony orchestra. Acta Acust. United Acust. 2008, 94, 856-865. [CrossRef]

200. Böhm, C.; Fiedler, F.; Weinzierl, S.; Holter, E.; Muth, S.; Schaefer, U.; Schwesinger, S. An Anechoic Recording of Ciceros 3rd Cataline Oration: Italian, Latin and German. 2019. Available online: http:/ / dx.doi.org/10. 14279/depositonce-8536 (accessed on 3 July 2020).

201. D'Orazio, D. Anechoic recordings of Italian opera played by orchestra, choir, and soloists. J. Acoust. Soc. Am. 2020, 147, 157-163. [CrossRef] [PubMed]

202. D'Orazio, D.; De Cesaris, S.; Garai, M. Recordings of Italian opera orchestra and soloists in a silent room. Proc. Meet. Acoust. 2016, 28, 015014. [CrossRef]

(C) 2020 by the authors. Licensee MDPI, Basel, Switzerland. This article is an open access article distributed under the terms and conditions of the Creative Commons Attribution (CC BY) license (http://creativecommons.org/licenses/by/4.0/). 